Historic, Archive Document

Do not assume content reflects current scientific knowledge, policies, or practices. 

62,57
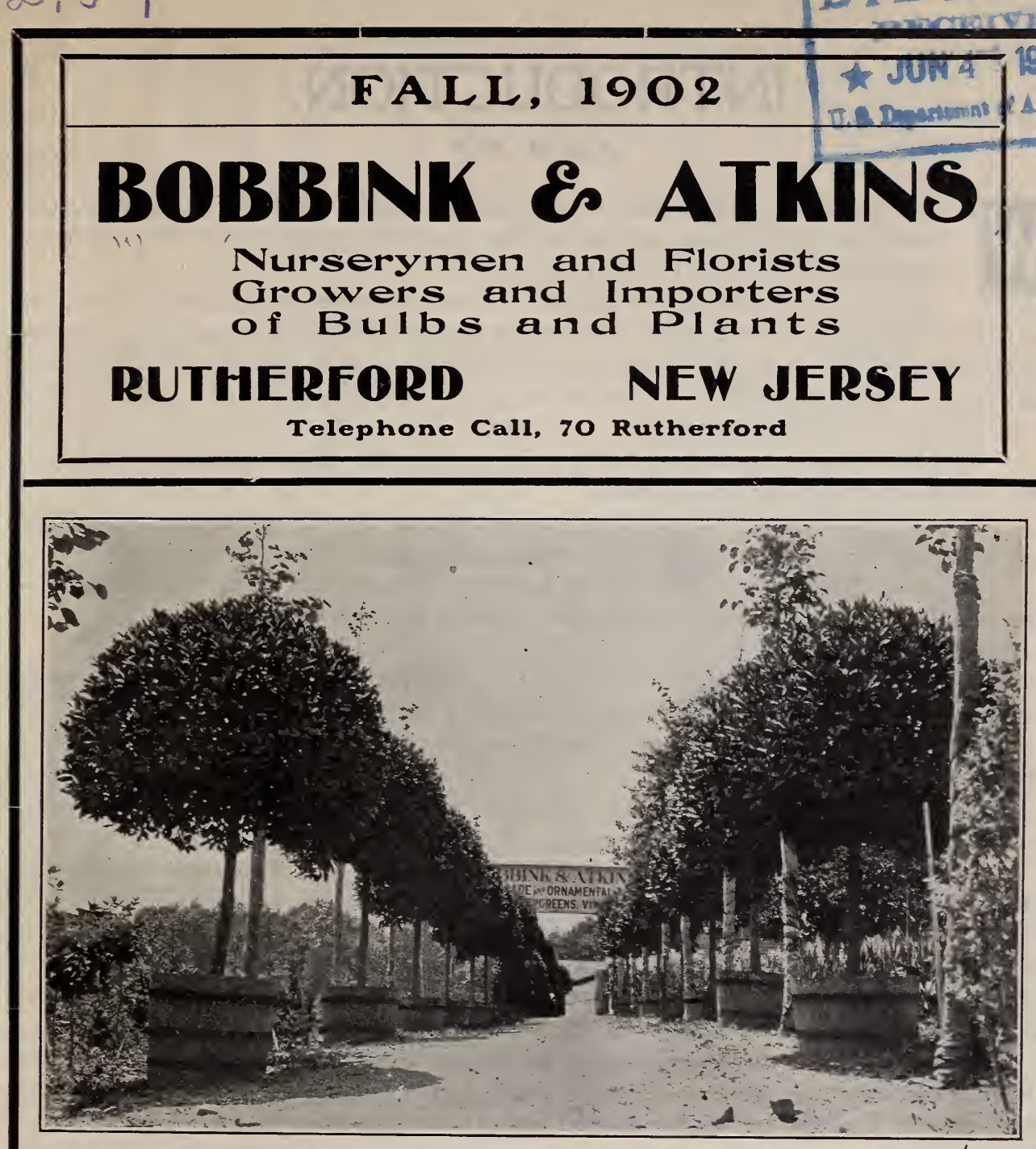

Greenhouses, Nurseries, Warehouses, Storage Cellars and Offices are Situated at Carlton Hill, East Rutherford, New Jersey

\section{...Catalogue of...}

DUTCH, FRENCH J APANESE AND OTHER $x * x+x$

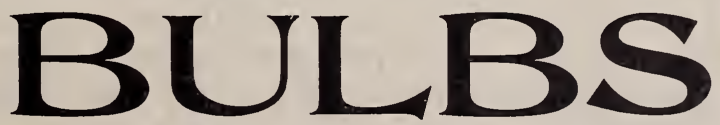

Azalea Indica Rhododendrons Fern Balls Palms Roses Paonia Bay Trees Boxwood Boston Ferns Hardy Herbaceous Plants, Etc. 


\section{* * * * *}

$\mathbf{W}$

E take pleasure in presenting to you our Catalogue for the Fall of 1902, and thank our friends and patrons for their generous support and complimentary letters received during the past season.

Our range of greenhouses and storehouses now cover 100,000 square feet, and our nurseries 60 acres of land, which will help us in giving the needs of our patrons better attention than ever. It is our constant aim to furnish the best of all kinds of horticultural stock our European connection enables us to supply, thus giving our patrons the benefit of our travels and lifelong experience.

We solicit your patronage, knowing fully well we can supply the class of stock you need to beautify your grounds and home.

If there is anything you want, not enumerated in this Catalogue, kindly send your order and same will be filled at the lowest market price.

We have extended our office facilities to meet the demands of our increasing business, enabling us to give your currespondence prompt and careful attention.

Prices in this Catalogue are F. O. B. Rutherford, N. J.

Important. This Catalogue cancels all previous prices, either in special lists, offers or catalogues. This rule will be strictly observed.

Orders from unknown correspondents must be accompanied by remittances or satisfactory references.

Terms. Accounts rendered first of every month; a cash discount of 2 per cent. allowed on all orders accompanied by cash.

Request your orders to be shipped by express. It will save you trouble and unnecessary delay. We will not be responsible for goods shipped by freight.

All errors and omissions in the execution of orders will be satisfactorily adjusted if we are notified immediately upon the receipt of goods.

We warrant our stock to be as represented in this Catalogue, but do not guarantee crops or assume any responsibility after the stock leaves our hands.

Head Gardeners and Assistants. We have on file a list of competent and reliable gardeners awaiting engagements. Parties needing proficient men for these positions will probably secure better and more practical men through us than on their own responsibility. We make no charges, our only wish being to assist our customers in what is often a difficult matter.

Visitors. Our nurseries are always open to visitors; inspection of our stock will convince you we are filling our orders with the finest class of stock grown. We will be pleased to have any one interested in gardening visit our nurseries, situated at East Rutherford, N. J., where we have on hand quantities of stock of our own growing, in addition to a line of the different stocks in season from the firms which we represent, thus facilitating inspection and the prompt execution of orders.

Trusting to again hear from you and your friends, promising our best efforts to give satisfaction, 


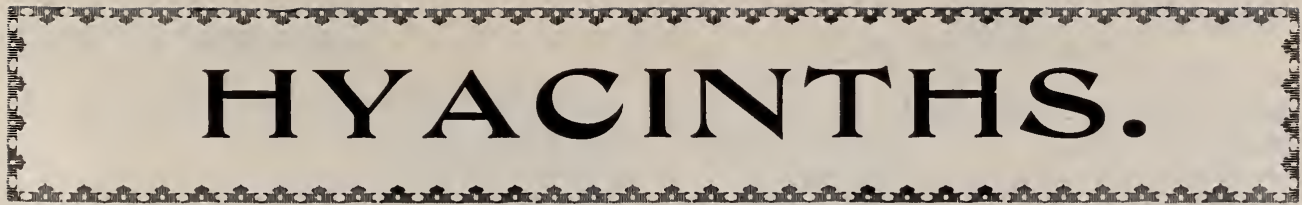

Hints on the Culture of the Hyacinth.

HYACINTHS IN GLASSES.

Fill the glass so as to touch the base of the bulb with clear water, putting in a small piece of charcoal. After filling the glasses they should be placed in a cool, dry, dark place for a month, till the roots reach about the bottom of the glass, when they may be brought to the light. Attention is required to keep a sufficient supply of water in the glass, and looking over the bulbs while growing, to brush off any decayed skin that may be on the bulb. The water should be changed every two or three weeks.

\section{HYACINTHS IN POTS.}

For the culture of the Hyacinth in pots it is of the greatest importance to have a good light rich soil; rich loam, decayed cow manure and sand in equal proportions will suit them best. When potting leave the top of the bulb level with the surface of the soil; four or five inch pots are the best sizes to use. After potting place them on a bed of wet ashes or ordinary soil, and cover them to a depth of five or six inches. When well rooted, which will be in about six weeks, they may be removed indoors. The best time for planting is October and November.

\section{HYACINTHS IN BEDS AND BORDERS.}

The best time for planting these is October or November, in light rich soil, which should previously be dug to a depth of 18 inches. The bulbs may be planted six inches apart and five inches deep. To protect the bulbs against severe weather the beds or borders should have a light covering of small litter straw or hay, which should be removed about the end of March.

\section{FRENCH ROMAN HYACINTHS}

\section{FOR HOUSE CULTURE ONLY.}

These are the earliest of all Hyacinths; if planted in September and October they will bloom from the middle of November till Christmas. Plant three bulbs in a 5 -inch pot. Early White, Ist size, Each. doz. Ioo. II-I2 cent .......... \$o 04 \$o 40 \$2 50

Early White, extra selected, I2-I5 cent...... 06 $50 \quad 300$

Early White, Italian, red skin bulbs ........... 05 50 250

Early Blue .............. $04 \quad 40 \quad 250$

Early Light Rose ....... $04 \quad 40 \quad 250$

Early Dark Rose ........ $04 \quad 40 \quad 250$

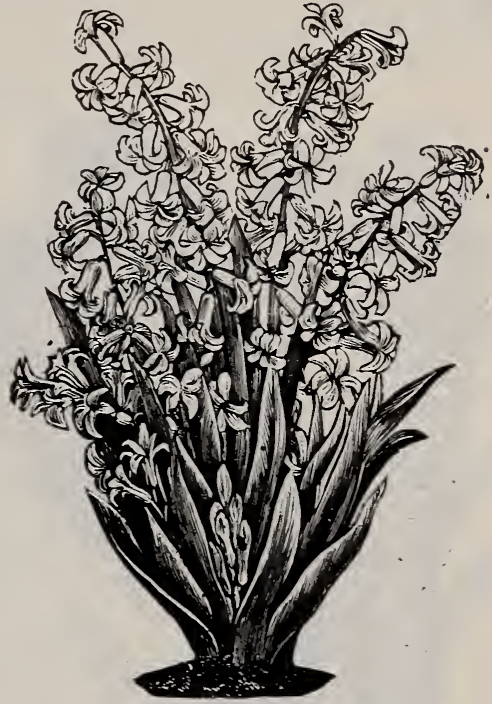

Roman Hyacinths, White.

\section{DUTCH ROMAN HYACINTHS.}

These bloom about six weeks later than the early French Romans. Very effective for growing in pots, pans or boxes indoors; also suitable for outdoor bedding.

Single White.

Single Dark Red.

Single Light Blue.

Price, each Ringle Dark Blue.. $\$ 2.75$.

\section{DUTCH HYACINTHS.}

Mixed Grade. Best Quality. Suitable for Forcing or Bedding.

Parties who intend planting large beds or borders with Hyacinths, Tulips, Crocus, Narcissus, etc., will do well by communicating their wants to us, stating space to be covered, and we will suggest varieties, quantities and prices for same.

Single, dark red.

Single, rose or pink.

Single, red, all shades.

Single, pure white.

Single, blush white.

Single, white, all shades.

Single, light blue.

Single, dark blue.

Single, blue, all shades.

Single, yellow.

Single, all colors, mixed.

Price, each, 5 cts.; per doz., 50 cts.; per 100 , $\$ 4 ;$ per $1000, \$ 37.50$. 


\section{FYACINTHS-Continued.}

Double, dark red.

Double, pink.

Double, red, all shades.

Double, pure white.

Double, blush white.

Double, white, all shades.

Double, light blue.

Double, dark blue.

Price, each, 5 cents.; per doz., 50 cts.; per I00, $\$ 4$.

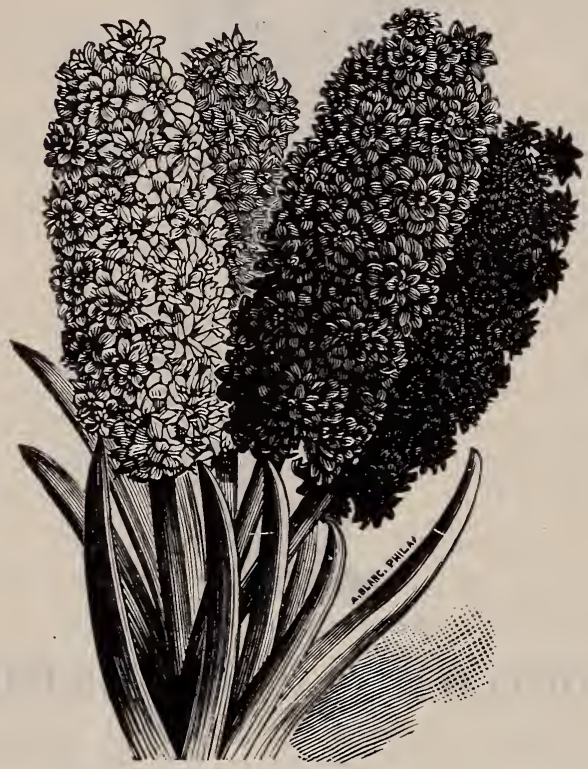

Double Hyacinth.

\section{STRICTLY FIRST-SIZE NAMED HYACINTHS.}

The superiority of first size named Hyacinths for pot culture and growing in water is attested by the increased sales of the past few years. They will always produce large full spikes, which will certainly give better satisfaction than the smaller blooms produced by the mixed grade.

To those who are not well acquainted with the best varieties of Hyacinths, we recommend the following collections. They are put up in the most liberal manner as to value and contain only varieties calculated to make an effective display.

\section{OUR SELECTION FOR POTS AND GLASSES.}

Collection of 50 in 50 choice varieties,

Hyacinths ................... \$5 00

Collection of 25 in 25 choice varieties, Hyacinths .................. 250

Collection of 12 in 12 choice varieties, Hyacinths $\ldots \ldots \ldots \ldots \ldots \ldots \ldots \ldots \ldots \ldots$ I I $_{5}$

Collection of 6 in 6 choice varieties, Hyacinths ....................
SINGLE RED AND ROSE HYACINTHS.

Baron van Thuyll, rose, early.

Cosmos, dark rose.

Fabiola, pink, large truss, late.

General Pelissier, dark red, very early.

Gertrude, dark pink, large spike.

Gigantea, delicate rose, large spike.

Lord Macaulay, dark rose, extra fine.

Norma, waxy pink, large bell, early.

Robert Steiger, deep red, fine spike.

Roi des Belges, finest dark red, large.

Victoria Alexandrina, dark red, late.

Price, each, Iо cts.; per doz., \$1.00; per I00, $\$ 7.50$.

\section{SINGLE WHITE AND BLUSH WHITE HYACINTHS.}

Alba Superbissima, early, pure white.

Baroness van Thuyll, pure white, very early.

Elfride, blush white, large bells.

Grande Vedette, pure white, good spike.

Grandeur a Merveille, blush, large truss.

La Franchise, blush white, late.

La Grandesse, purest white, one of the best.

La Pucelle d'Orleans, pure white.

Mme. van der Hoop, white, large spike.

Paix de l'Europe, pure white, late.

Queen Victoria, pure white, large bells.

Voltaire, blush, good spike.

Price, each, Io cts.; per doz., \$1.00; per I00, $\$ 7.50$.

\section{SINGLE BLUE, LIGHT BLUE HYA- CINTHS.}

Baron van Thuyll, early, dark blue.

Blondin, purple blue, larse truss.

Chas. Dickens, lilac blue, early.

Czar Peter, porcelain blue, large spike.

Grand Lilac, lilac blue, compact truss.

Grand Maitre, deep porcelain blue, large spike.

King of the Blues, finest dark blue, large.

La Peyrouse, light blue, good spike.

Leonidas, bright blue, early.

Marie, purple blue, grand spike.

Pieneman, dark porcelain blue, large bells.

Regulus, pale blue, very fine.

Queen of the Blues, light, fine spike.

Uncle Tom, dark blue.

Price, each, Io cts.; per doz., \$1.00; per I00, $\$ 7.50$.

\section{SINGLE YELLOW HYACINTHS.}

Hermann, orange yellow.

Ida, pure yellow, fine spike.

La Citroniere, clear yellow.

La Pluie d'Or, bright yellow.

Price, each, Io cts.; per doz., \$I.0o; per Ioo, $\$ 7.50$.

\section{DOUBLE RED HYACINTHS.}

Per Per

Each. doz. Ioo.

Bouquet Royal, salmon rose...\$o Io \$I $00 \$ 750$

Bouquet Tendre, carmine red.. Io I 00750

Czar Nicholas, rose......... Io I oo 750

Grootvorst, rose, large truss... Io I oo 750

Prince of Orange, dark rose,

large...$\ldots \ldots \ldots \ldots \ldots$.......... Io 750 
GYACINTHS-Continued.

DOUBLE WHITE HYACINTHS.

Per Per Each. doz. roo.

Anna Maria, blush white..... \$0 I0 $\$ 100 \$ 75^{\circ}$

Bouquet Royal, pure white.... Io I 00750

La Tour d'Auvergne, pure

white, early .............. Io I 00750

La Virginite, blush white., late Io I oo 750
DOUBLE YELLOW HYACINTHS.

Per Per

Bouquet d'Orange, orange yel-Each. doz. Ioo. low .................. \$o Io $\$ 1$ oo $\$ 750$ DOUBLE BLUE HYACINTHS.

Bloksberg, porcelain blue..... I0 I 00750 Chas. Dickens, lilac blue, early io I oo 750

Prince of Saxe Weimar, dark

blue ................... Io I oo 750

Rembrandt, porcelain blue, late Io I 00750

\section{TULIPS.}

Treatment same as Hyacinths. Plant 3 bulbs in a 5 -inch pot.

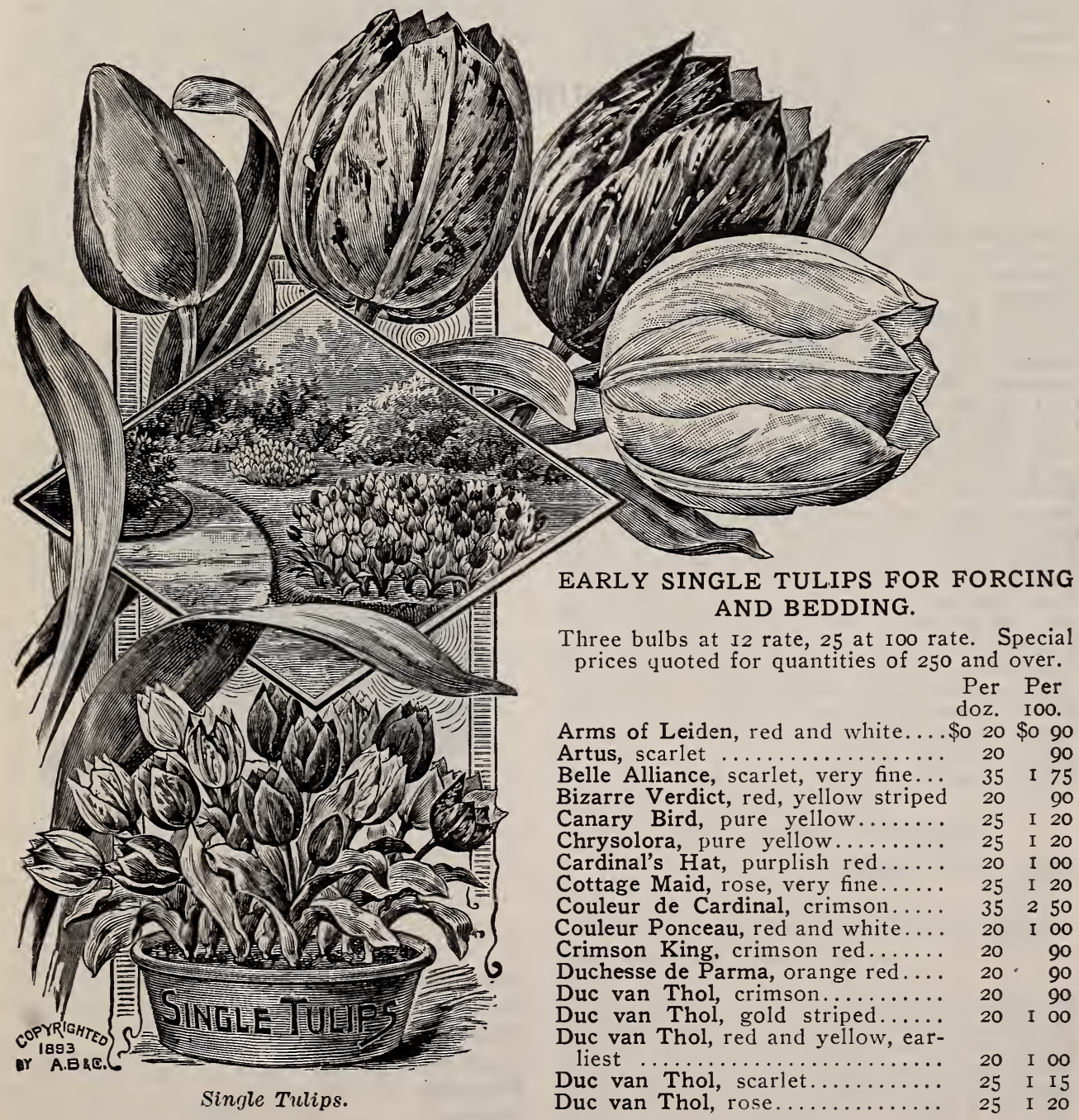


EARLY SINGLE TULIPS-Continued.

Per Per

doz. IOO.

Duc van Thol, white..........\$O 25 \$I 25

Duc van Thol, vermilion........ 20 I 00

Duc van Thol, yellow......... $30 \quad 200$

Jacht van Delft, white, late forcing 20 I 00

Joost van Vondel, cherry red and

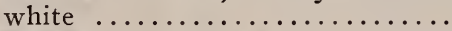

Keizerskroon, scarlet, yellow edged

L'Immaculee, pure white.........

La Reine, white, shaded rose.....

Mon Tresor, pure yellow.........

Ophir d'Or, large yellow..........

Pottebakker, scarlet .............

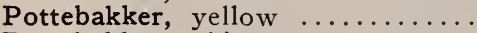

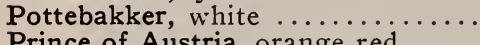

Prince of Austria, orange red......

Princess Marianne, white.........

Proserpine, carmine rose ........

$\begin{array}{lll}25 & \text { I } & 20 \\ 25 & \text { I } & 20 \\ 25 & \text { I } & 20 \\ 20 & \text { I } & 00 \\ 35 & 2 & 25 \\ 35 & 2 & 25 \\ 25 & \text { I } & 20 \\ 30 & \text { I } & 50 \\ 30 & \text { I } & 40 \\ 35 & 2 & 25 \\ 25 & \text { I } & 20 \\ 40 & 2 & 25\end{array}$

Per Per

doz. roo.

Purple Crown, purple red........\$O $20 \$ \mathrm{I} \infty$

Queen Victoria (La Reine), white, shaded rose ................ 20 I 00

Rose Grisdelin, rosy .......... 25 I 50

Rose Luisante, fine dark rose.... 50 350

Rosamundi, rosy pink ......... 25 I 20

Standard Gold, red, gold striped... 40250

Standard Silver, red, white striped. 25 I 25

Thomas Moore, orange........ 25 I 50

Van der Neer, violet........... 25 I 20

Vermilion Brilliant, fine scarlet.... $35 \quad 275$

Wouverman, violet ........... 20 I 00

Yellow Prince, yellow............. 25 I 20

Early Single Tulips, fine mixed (per I000, $\$ 6.50) \ldots \ldots \ldots \ldots \ldots$ I5 80

Early Single Tulips, extra fine mixed (per I000, $\$ 7.50) \ldots \ldots \ldots .20$ I 00

\section{EARLY DOUBLE TULIPS.}

Three bulbs at 12 rate, 25 at 100 rate. Special prices quoted for quantities of 250 and over.

Per Per doz. roo.

Alba Maxima, pure white........ \$o 35 \$I 75

Blue Flag, violet blue........... 30 I 50

Couronne d'Or, yellow.......... 60 4 oo

Cousine, violet .............. 30 I 25

Duke of York, red, white bordered 25 I 25

Duc van Thol, red, yellow edged.. 20 I IO

Gloria Solis, red, yellow edged... 25 I 25

Imperator Rubrorum, scarlet ..... $35 \quad 2$ oo

La Candeur, white, late......... 20 I IO

Lady Grandison, scarlet, dwarf.... 25 I 25

Lady Palmerston, new, fine pink... $50 \quad 250$

Le Blason, rosy ............. 30 I 80

Murillo, rosy ................ $40 \quad 250$

Pæonia Red, red striped.......... 30 I 20

Pæonia Gold, gold striped....... 30 I 40

Purple Crown, dark red.......... 20 I Io

Rosine, rosy $\ldots \ldots \ldots \ldots \ldots \ldots \ldots .35$ I 50

Rose Blanche, pure white......... 25 I 25

Rex Rubrorum, scarlet.......... 35 I 50

Tournesol, red and yellow, early.. 25 I 40

Tournesol, yellow, early......... 50 350

Salvator Rosa, white and deep rose $50 \quad 350$

Yellow Rose, golden yellow, late.. 20 I Io

Early Double Tulips, fine mixed (per 1000, \$7.00)..............

Early Double Tulips, extra fine mixed (per I000, $\$ 8.00$ ).........

DOUBLE LATE TULIPS.

Extra Fine Mixture (per Iooo

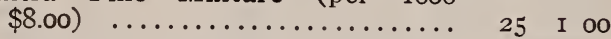
SINGLE LATE FLOWERING TULIPS.

Per Per doz. IOO.

Bizarres, finest mixed ......... \$o 20 \$I Io

Bouton d'Or, pure yellow............ $35 \quad 2 \quad 00$

Byblooms, violets, mixed.......... 20 I 25

Byblooms, roses, mixed........... 20 20 I 25

Breeders, finest mixed........... 25 I 75

Darwin Tulips, finest mixed....... $30 \quad 300$
Per Per

Doz. roo.

Gesneriana, scarlet, common......\$O 25 \$ I 50

Gesneriana, scarlet, true ........ 30 I 75

Golden Crown, yellow, edged red. 20 I 25

Maiden Blush, white, pink edged.. $40 \quad 300$

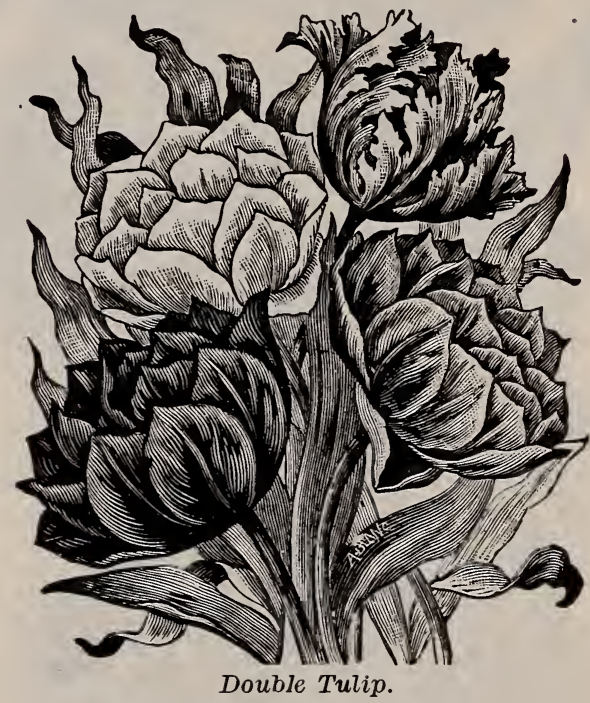

PARROT TULIPS.

Per Per doz. roo.

Extra Fine, mixed (per I000, \$9.00) \$0 20 \$I oo Constantinople, red $\ldots \ldots \ldots \ldots . \quad 25$ I 25 Cramoisi Brillant, fine carmine red. $40 \quad 2 \quad 25$ Lutea Major, yellow............ 25 I 25 Markgraf, red and yellow........ 25 I 25 Perfecta, yellow, flamed scarlet... 25 I 25 


\section{NARCISSUS, or DAFFODILS.}

Plant three bulbs in a 5-inch pot.

All Narcissus and Daffodils are hardy, with the exception of the Polyanthus group, these requiring a covering of litter over Winter. For indoor growing Narcissus require the same treatment as Hyacinths.

$\begin{array}{rll}\text { Per } & \text { Per } & \text { Per } \\ \text { Each. doz. } & \text { IOo. } & \text { IOoo. }\end{array}$

Von Sion, Dutch grown, mammoth bulbs.....\$o o5 \$0 $40 \$ 250 \$ 2250$

Von Sion, extra selected bulbs .............. $03 \quad 30 \quad$ I $60 \quad$ I5 00

Von Sion, Ist size bulbs $02 \quad 20$ I 40 I2 00

Double Roman (Constantinople) ........

Alba Plena Odorata, pure white .......... $03 \quad 20$ I $00 \quad 900$

Incomparable, lemon \& orange $\ldots \ldots \ldots \ldots \ldots$. $03 \quad 20$ I $00 \quad 850$

Orange Phœnix, orange and white $\ldots \ldots \ldots . .64 \quad 35 \quad 200 \quad$ I8 00

Silver Phœnix, pale creamy white $\ldots . .$. I 5 I $50 \quad 950$

\section{JONQUILS.}

Plant six bulbs in a 5 -inch pot.

Per Per

Each. doz. Ioo.

Single, sweet scented, yellow.\$o 02 \$o I5 $\$ 060$

Double, sweet scented yellow. $04 \quad 35 \quad 225$

Campernelle, large, single yellow .................. 02 I5 75

Campernelle Regulosus (Improved Campernelle) ...... $03 \quad 25 \quad$ I 00

\section{SINGLE DAFFODILS.}

Plant 3 Bulbs in a 5 -inch Pot. Three Bulbs at I2 Rate, 25 at roo Rate. Special Prices quoted for Quantities of 250 and over.

Per Per Each. doz. Ioo.

Bicolor Empress, yellow trumpet, white perianth........ \$o ro \$o $75 \$ 400$

Bicolor Grandee, large yellow trumpet, white perianth, late

Bicolor Horsfieldi, early, yellow trumpet, pure white perianth $\ldots \ldots \ldots \ldots \ldots \ldots \ldots$.

Bulbocodium (Hoop petticoat) yellow ...................

Emperor, largest yellow trumpet, primrose petal.........

Golden Spur, large golden trumpet, early .............

Henry Irving, yellow trumpet, large flower ...............

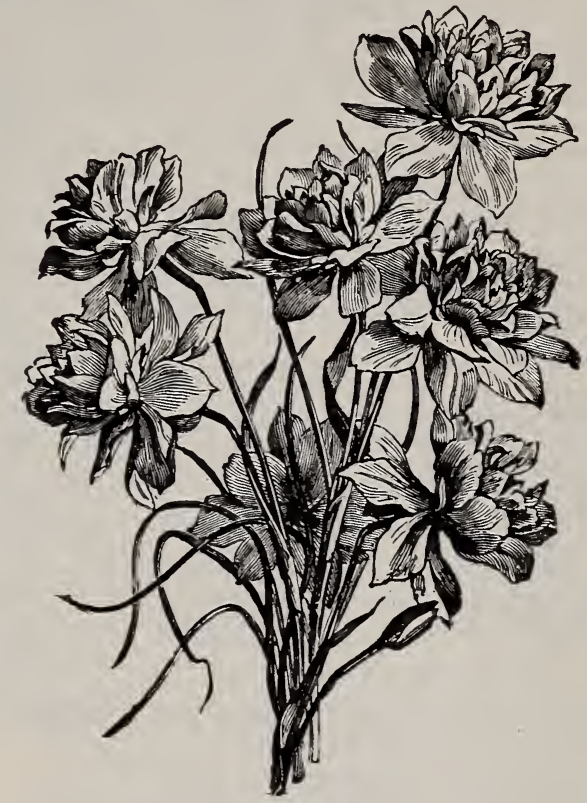

Jonquils.

$\begin{array}{rr}\text { Per } & \text { Per } \\ \text { Each. doz. Ioo. }\end{array}$

Incomparable, yellow, orange cup ..................\$O $0_{3}$ \$O 20 \$I 00

Incomparable Stella, white, orange cup ................ $03 \quad 20$ I 00

Incomparable Cynosure, white, yellow cup ..............

Incomparable Figaro, cup orange, yellow petals.........

Incomparable Sir Watkin, yellow cup, petals lemon, very

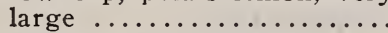
Leedsii Alba, white...........
Obvallarius (Tenby Daffodil), yellow, early ............

Poeticus (Pheasant's Eye), white, orange cup (per Iooo, \$4.00) ..................

Poeticus Ornatus, white, early

Princeps, yellow trumpet, sulphur petals ...............

Rugilobus, pale yellow trumpet

Trumpet Major, golden yellow

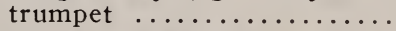

Trumpet Maximus, largest golden trumpet ..........

Mixture of Trumpet Sorts (per I000, \$I2.00)...........

Mixture of all Varieties......

\section{$0320 \quad$ I 00 \\ $04 \quad 25 \quad$ I 25}

I0 $75 \quad 400$

$03 \quad 20 \quad$ I 25

$05 \quad 50 \quad 300$

O2 $15 \quad 50$

$0320 \quad$ I OO

$\begin{array}{lll}05 & 25 & \text { I } 25\end{array}$

$05 \quad 45 \quad 350$

0325 I 50

I0 $65 \quad 400$

$04 \quad 25$ I 50

03 I5 I 00 


\section{POLYANTHUS NARCISSUS.}

These are not hardy and require a covering over Winter. Plant three bulbs in a 5 -inch pot. Three bulbs at 12 rate; 25 at 100 rate.

Special prices quoted for quantities of 250 and over. Per Per

Early Double Roman, white doz. I00. yellow center............. \$o 03 \$o 25 \$I 50 Gloriosa, white, orange cup... $04 \quad 30 \quad 225$ Grand Monarque, white, yellow cup ................ $04 \quad 30 \quad 225$ Grand Primo, white, citron cup $04 \quad 30 \quad 225$ Grand Soleil d'Or, orange-yellow ................... $04 \quad 30 \quad 225$ Jaune Supreme, yellow, orange

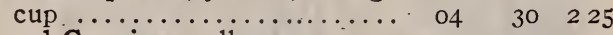
Lord Canning, yellow............ 04 30 225

Newton, fine, deep yellow.... $04 \quad 04 \quad 30 \quad 225$

States General, white.......... $04 \quad 30 \quad 225$

States General, yellow......... $04 \quad 30 \quad 225$

CHINESE SACRED NAR-

CISSUS .............. I0 856.00 (Per original basket of 30 bulbs, $\$ 1.80$. )

Mixture of Yellow Polyanthus

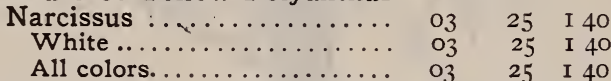

NARCISSUS PAPER'IWHITE GRANDIFLORA.

The popular white Narcissus from France. If planted in September, will bloom in December.

Per Per Per Each. doz. I00. I000. Large Selected Bulbs...\$0 04 \$0 25 \$I 50 \$1200 Large Mammoth Bulbs. $06 \quad 35 \quad 225$ I8 o0

\section{CALLAS.}

One of the best plants for house culture; flowers large, pure white. Per Per Each. doz. Ioo. First Size Bulbs........... \$o.Io \$I I $5 \$ 850$ Selected Large Bulbs......... 20 I 80 I2 50 Mammoth Bulbs .............. $30 \quad 300 \quad 2000$

\section{FREESIAS.}

Very free blooming bulbous plants for house culture; flowers in clusters, pure white.

Per Per Each. doz. Ioo. Refracta Alba, first size..... \$0 02 \$o I5 \$0 75 Refracta Alba, selected bulbs.. $03 \quad 20$ I 00 Refracta Alba, mammoth..... $0550 \quad 300$

\section{CROCUS.}

This is one of the earliest Spring flowers, and one of the easiest to grow; they will thrive in any soil and situation. Crocus should be planted two to three inches apart, from September till December. For growing in pots, treat same as Hyacinths, but plunge the pots only about three inches deep. Plant from seven to ten bulbs in a five-inch pot.

Three bulbs at 12 rate, 25 at Ioo rate, 250 at I000 rate.

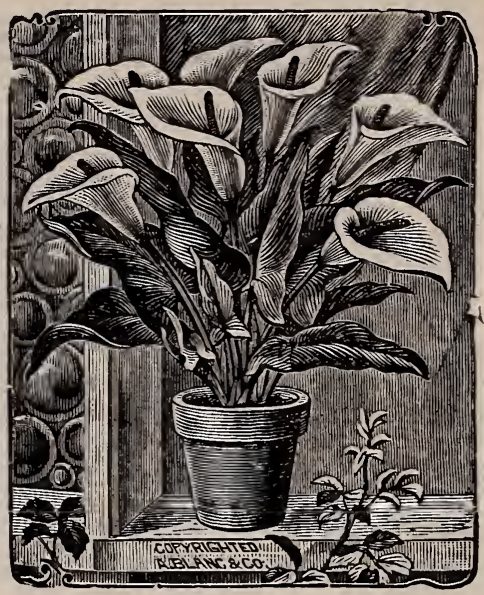

Calla.

NAMED LARGE FLOWERING CROCUSMammoth Bulbs.

Albion, striped.

Baron von Bruno, purple.

Caroline Chisholm, white.

Cloth of Gold, yellow striped.

Cloth of Silver, blue, white striped.

David Rizzio, purple.

King of the Blues, large blue.

Madame Mina, violet striped

Non Plus Ultra, purple, white edged.

Mont Blanc, large white.

Purpurea Grandiflora. large purple.

Queen Victoria, white.

Sir Walter Scott, violet striped.

Price, per doz, I5c.; per Ioo, 6oc.; per I0oo, $\$ 400$.

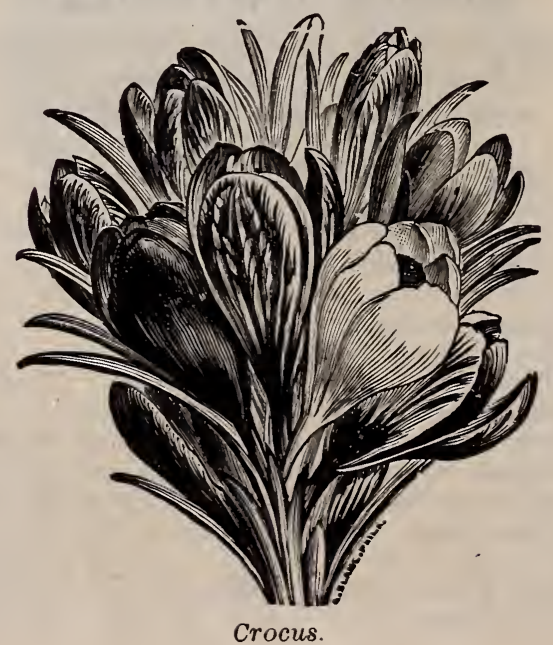


MIXED CROCUS-All Blooming Size Bulbs.

$$
\text { Per doz. Ioo. Iooo. }
$$

Large white ............. \$o Io \$o $35 \$ 275$

Large blue or purple ......... I0 $35 \quad 275$

Large striped and variegated. I0 $\begin{array}{llll}35 & 275\end{array}$

Large yellow .............. I0 $35 \quad 275$

Large, all colors, mixed...... Io $35 \quad 275$

\section{LARGE YELLOW CROCUS.}

Per Per Per doz. Imc. rooo.

Mammoth Bulbs ........... \$o 30 \$ 00 \$8 00 Extra Selected Bulbs ....... 20 60 500 First Size Bulbs........... Io 40 I0 300

\section{LILIUM LONGIFLORUM. JAPAN GROWN.}

Similar to the Lilium Harrisii or Easter Lily. Per Per

Mammoth Bulbs, 9-10 inches Each. doz. Ioo. circumference ........... \$0 $20 \$ 200 \$ 1000$ Extra Selected, 7-9 inches circumference $\ldots \ldots \ldots \ldots \ldots$ I $\ldots$ I $125 \quad 600$ First Size, 6-8 inches circum. . Io 80 400 For all varieties of Lilies not enumerated in this catalogue, prices quoted on application.

\section{SPIRAEA.}

Suitable for pot culture, also for outdoor planting. Three bulbs at 12 rate, 25 at ioo rate. Per Per Japonica Each. doz. IOO. Japonica Aurea Reticulata.... Io I 00 600 Astilboides Floribunda........ Io I 00 , 600 Compacta Multiflora ......... Io I 00 . 6 oo Gladstone, new ........... 354002500 Palmata Alba ............. Io I oo 6 oo Palmata Elegans .......... Io I 00 o 600 Palmata Rubra ............ Io I 00 o 600 Ulmaria ................ Io I 00 o 600 Filipendula, Flore Pleno..... Io I 0 . 600

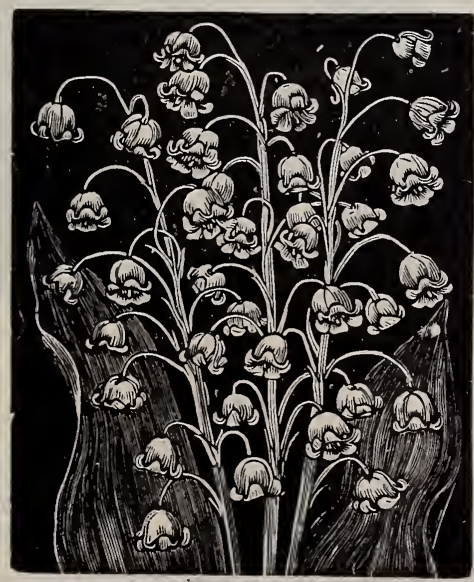

Lily of the Valley.

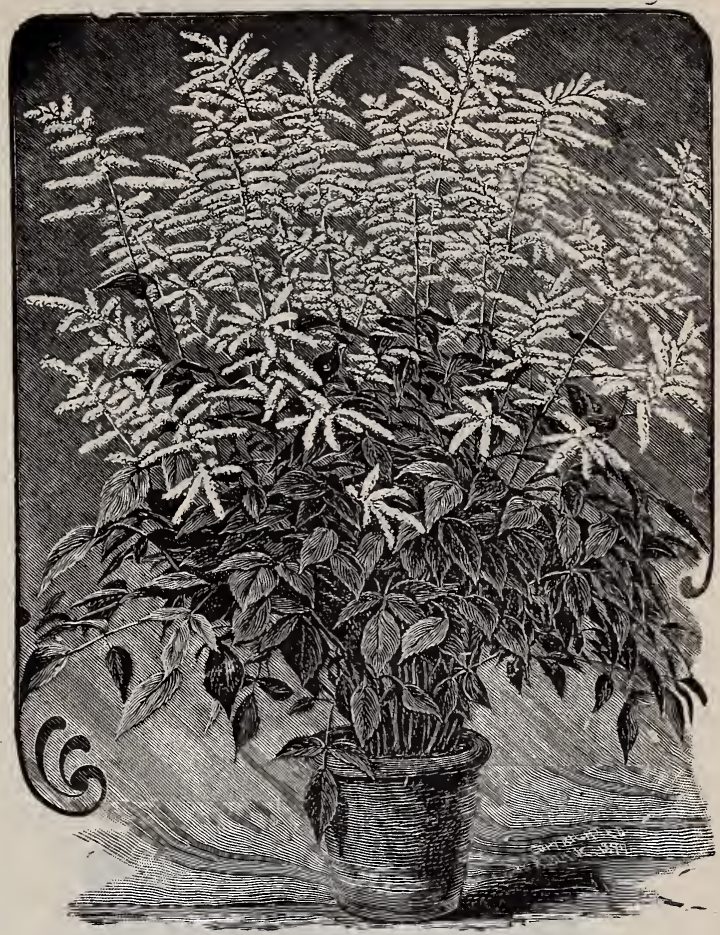

Spircea Astilboidcs.

\section{LILY OF THE VALLEY.}

Invaluable for forcing and planting out of doors.

Per Per Per doz. Ioo. Iooo.

Berlin Pips, large flowering early ................. \$0 25 \$ 50 \$ 4400 Hamburg Pips, large flower-

ing, late................ 25 I 50 I4 00 Strong Clumps $($ each $25 \mathrm{c}$.)... 250 i 8 oo

\section{PAEONIAS.}

Hardy herbaceous perennials of easy culture.

Per Per Each. doz. Ioo.

Officinalis, crimson........ \$O I5 \$I 60 \$I 300

Officinalis, white..................... $25 \quad 2502000$

Officinalis, rose........... 20200 I500

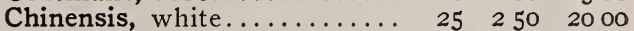

Chinensis, rose........... $20 \quad 200$ I500

Chinensis, finest mixture.... I5 I 50 I2 00

Pæonia Arborea (Tree Pæo-

nia) ................. $25 \quad 2502000$

Pæonia Tenuifolia (Fernleaved) ............. $25 \quad 2502000$ 


\section{IRIS.}

Hardy bulbous plants of easy culture and great beauty.

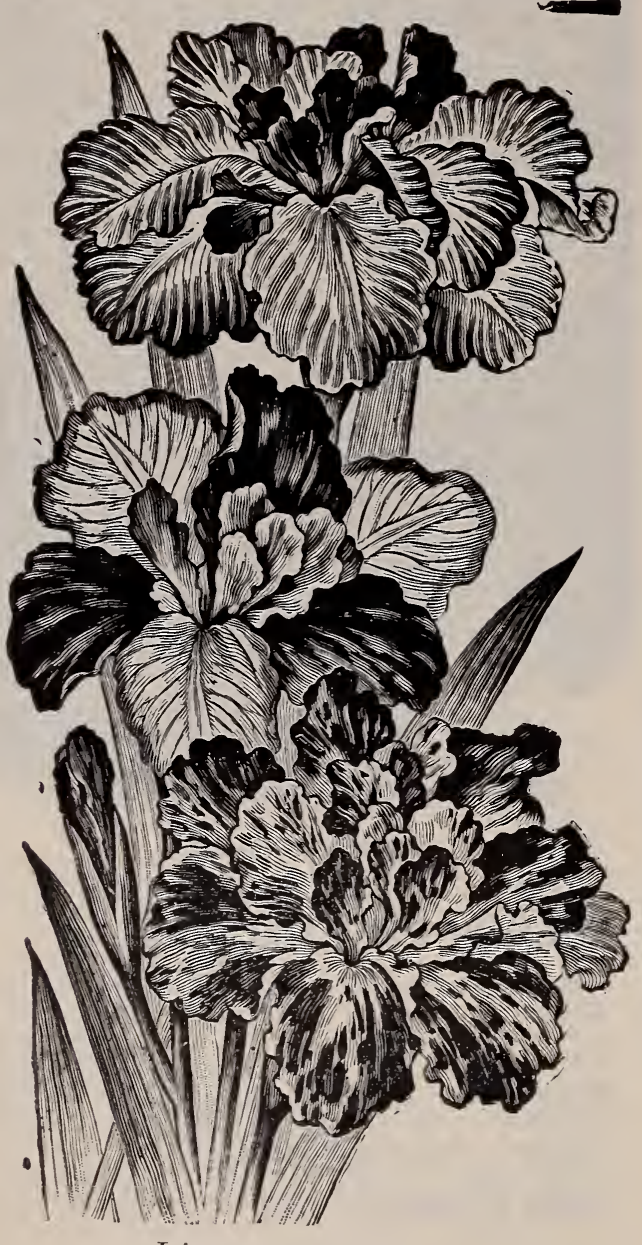

Iris.

Per Per

Each. doz. Ioo.

Anglica (English Iris), finest mixed, all colors...........

Hispanica (Spanish Iris), finest mixed, all colors, per IOOO, $\$ 3.50 \ldots \ldots \ldots \ldots$.

Germanica (German Iris), fin-

\$0 $20 \$ 100$ est mixed, all colors....... \$0 I5 I 00800

Kæmpferi (Japan Iris), finest mixed, all colors.......... 20 I 50 I0 00 (These require a liberal supply of water.)

\section{TUBEROUS BEGONIA.}

Very useful for house or greenhouse culture, and most valuable for bedding, flowering in great profusion all Summer. They should be started indoors in March or April, and planted outside at the end of May in partially shaded places. Three bulbs at 12 rate, 25 at 100 rate.

\section{LARGE SELECTED BULBS.}

Single white, single rose, single crimson, single orange scarlet, single yellow, single all colors, mixed. Price, each, 8c.; per doz., 75c.; per I00, $\$ 4.50$.

\section{NEW FRILLED TUBEROUS-ROOTED BEGONIA.}

Double white, double rose, double crimson, double orange scarlet, double yellow, double all colors, mixed. Price, each, I2c.; per doz., $\$ 1.25$; per I00, $\$ 8.00$.

A most unique form, with very large single and doubie flowers, which are entirely distinct from anything heretofore offered, the petals being wavy and beautifully frilled on the edges, similar to the newer form of Petunias. A decided acquisition. Strong bulbs, 25c. each; $\$ 2.50$ per doz.

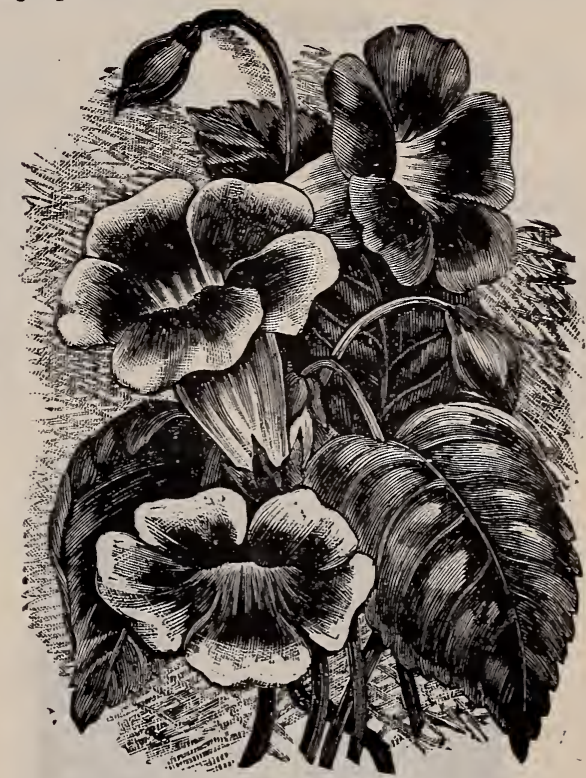

Gloxinia.

\section{GLOXINIAS.}

Our strain is unsurpassed; it is coxposed of the erecta and horizontal sorts only, combining the greatest variety of colors and markings; scarlet, white, blue, violet, spotted violet white edged, red white bordered, and mixed colors. Price, each, ro cts.; per doz., \$1.00; per I00, $\$ 6.00$. 


\section{AMARYLLIS.}

Probably the most magnificent and gorgeous bulbous plant known. Their immense flowers, richness of coloring and habit are simply incomparable. Strong Bulbs, each, 75 cts.; per doz., $\$ 8.00$.

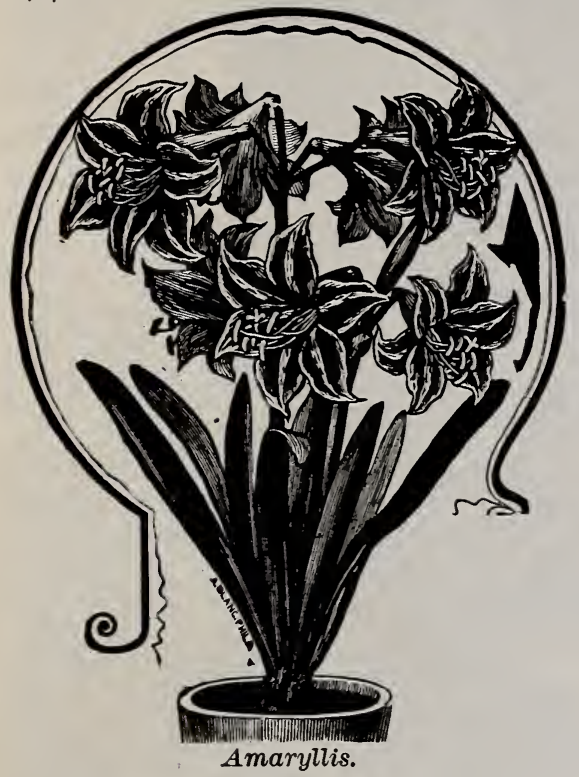

ISMENE CALATHINA.

Very large, pure white Amaryllis-like flowers. Strong Bulbs, each, 25 cts.; per doz., \$2.50.

\section{Fancy-Leaved CALADIUMS.}

Fancy-leaved Caladiums have in recent years grown rapidly in popular favor, not only for the decoration of the conservatory, greenhouse and window-boxes, but nearly all of the varieties succeed admirably if planted out of doors in partly shaded, sheltered borders, in wellenriched light soil; while for exhibition plants during the Summer and Fall months nothing can equal their beauty. Each, 25 cts.; per doz., $\$ 2.50$; per $25, \$ 5.00$.

\section{TRUE BERMUDA EASTER LILY-}

\section{LILIUM HARRISII.}

The best white Lily for Winter forcing. Per Per Each. doz. Ioo. First Size Bulbs ............ \$o I5 \$I o0 $\$ 600$ Extra Selected Bulbs ........ 25 I 75 I2 00 Mammoth Bulbs .............. $35 \quad 30028$ oo

\section{LILIUM CANDIDUM.}

\section{(St. Joseph's Lily.)}

Old-fashioned white garden Lily, suitable for forcing as well as outdoor planting.

Imported French Selected Stock. Price, each, I5 cts.; per doz., \$1.50; per 100, \$7.50.

\section{MISCELLANEOUS BULBS} AND PLANTS.

Allium Neapolitanum, pure white, valuable for forcing............ \$o I5 \$o 75

Anemone, single, The Bride, white.. 20 I 00

Anemone, single, scarlet......... 20 I 00

Anemone, single, mixed.......... 20 I 00

Anemone, double, scarlet......... 25 I 50

Anemone, double, mixed......... 25 I 50

Anomatheca cruenta (Scarlet Free-

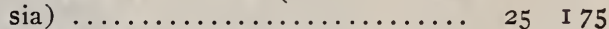

Camassia Esculenta, clear blue..... 25 I 00

Chionodoxa Luciliz (Glory of the Snow), blue .................

Crown Imperials, finest varieties, mixed (I5 cts. each)............ I Io 800

Cyclamen Giganteum, rose (20 cts. each) ................... I 75 I0 00 Crimson (20 cts. each)........... I 75 10 00 White (20 cts. each) ............ I 75 Io oo White, pink eye (20 cts. each) ..... I 75 I0 00

Dielytra Spectabilis (Bleeding Heart), very useful for forcing, also for outdoors (I5 cts. each).... I 25

Eranthis Hyemalis (Winter aconite)

Erythronium (Dog Tooth violets), mixed colors .................

Fritillaria Meleagris, mixed colors

Gladiolus Colvillei Alba, The Bride, fine for forcing ................

Gladiolus Colvillei Rubra ..........

Hyacinthus Botryoides (Grape Hyacinth), blue $\ldots \ldots \ldots \ldots \ldots \ldots \ldots$.

Hyacinthus Botryoides, white......

Hyacinthus Candicans, white (Summer flowering (5 cts. each)......

Ixias, finest English mixture........

Montbretia Crocosmiflora, scarlet (5

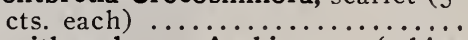

Ornithogalum Arabicum (white, black center), valuable for forcing (5 cts. each) ................ $40 \quad 250$

Ornithogalum Umbellatum, white... 20 I 00

Oxalis (Bermuda Buttercup), fine for pots ......................

Oxalis, mixed varieties..............

Oxalis, named var...............

Ranunculus, Fersian mixture.......

Ranunculus, French mixture.........

Ranunculus, Turban mixture....... I5

Scilla Sibirica, blue, for pots and outdoors .................. 20

Snowdrops, single...............

Snowdrops, single, Elwesi Giant.... I5

Snowdrops, double.............. 25

Sparaxis, finest mixture.............

Triteleia Uniflora, pure white....... 20

Tuberoses, Diora, pure white...... $20 \quad 75$

\section{JAPAN FERN BALLS. Dormant.}

Ready for delivery in December.

This has proved to be such an exquisite novelty that no home is complete without one. 75 cts. each; $\$ 6.00$ per dozen. 


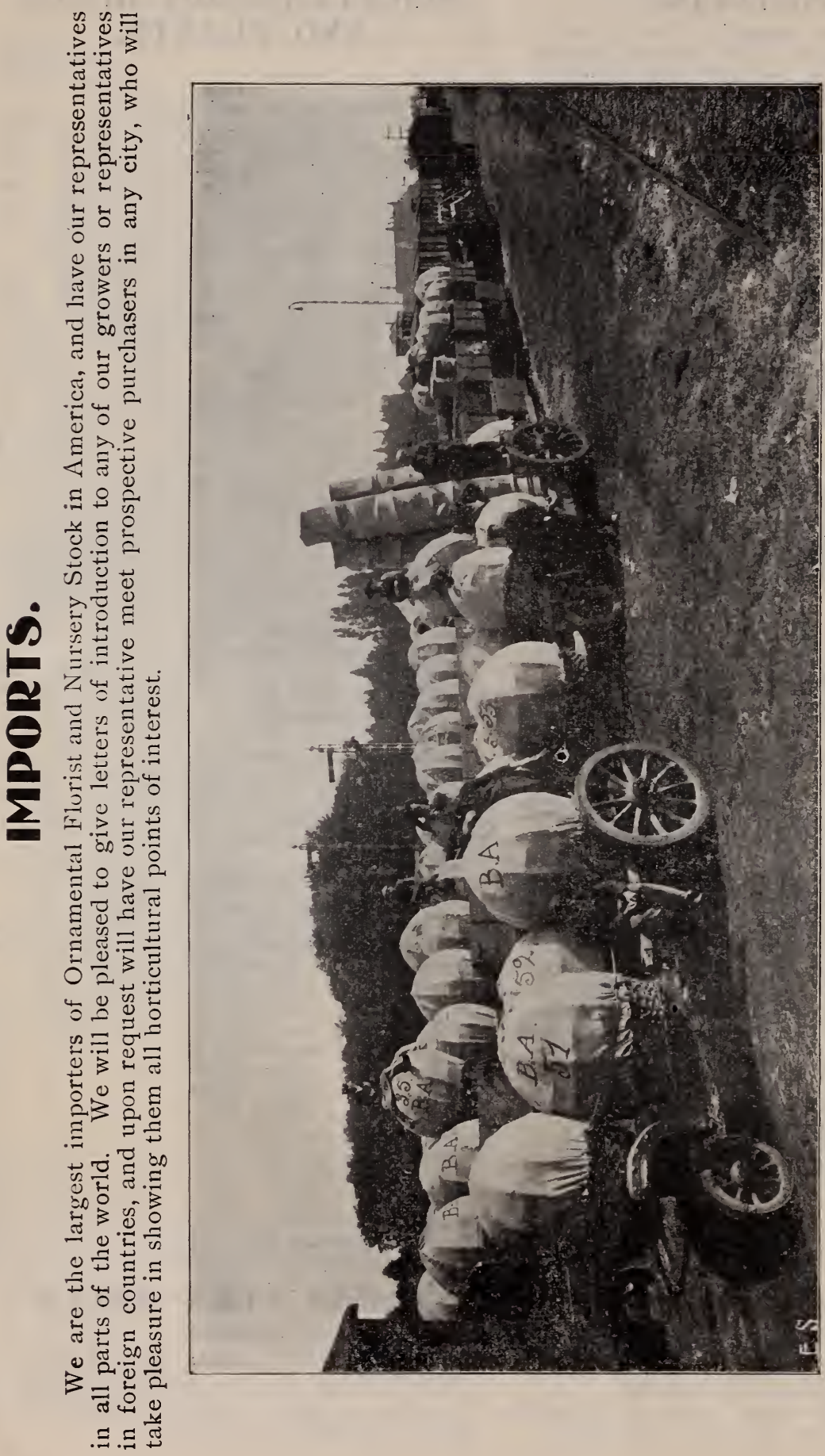

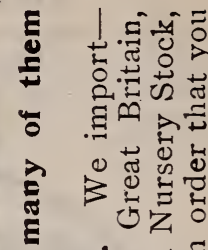

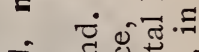

స

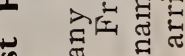

क ज क

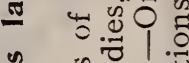

$\because \quad \Xi$

슬

उ च्वेत्ञ

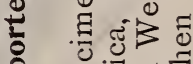

ह की

i क्ष

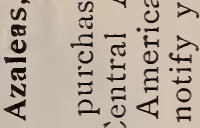

5 का

$\Xi$ 势

ह

के उच्त्र

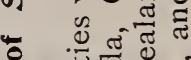

-

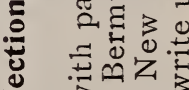

产

\& 8.00

\%

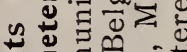

E

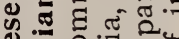

한 융

인.

呵元

원

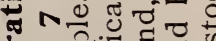

유.

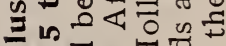

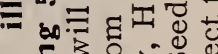

.

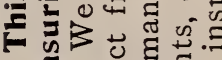

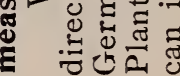




\section{Decorative Flowering and Forcing Plants.}

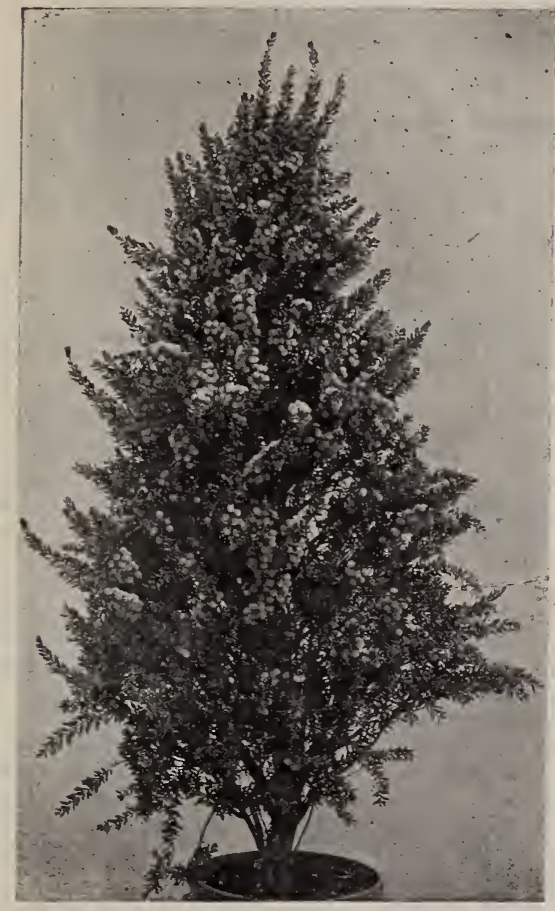

Acacia Armata.

\section{ACACIA.}

A. armata. (Paradoxa.) A pretty spring flowering variety which produces its flowers in globular heads from the axils of the foliage, in such a manner as to completely envelop the plant in a pleasing light yellow; an excellent plant for Easter forcing, succeeding under the same culture as the azalea. 5-in. pots, ea. 5oc., doz. $\$ 5.00$.

\section{ADIANTUM FARLEYENSE.}

We can supply any quantity of this most beautiful of ferns in all sizes. Our stock is first-class.

5-in. pots, per doz. \$12.00; 6-in. pots, per doz. $\$ 18.00 ; z$-in. pots, per doz. $\$ 24.00$.

Cut fronds can be shipped at any time at $\$ 12.00$ per Ioo.

\section{ARAUCARIA.}

A. excelsa (Norfolk Island Pine). 6-in pots, extra fine. Ea. \$2.00, doz. \$20.00.

A. excelsa glauca. 6-in. pots. Ea. \$2.50.

A. robusta compacta. 6-in. pots. Ea. \$2.50.

\section{ASPARAGUS.}

A. plumosus nanus. One of the finest decorative vines recently introduced; adapted to the same uses as smilax, as easily grown, and very much more beautiful on account of its light, feathery growth. Strong plants, ea. I5c.; doz. \$1.50; extra size, $3^{1 / 2-i n . ~ p o t s, ~ e a . ~} 25$ c., doz. $\$ 2.50$.

A. Sprengeri. One of the most rapid growing plants that we know of, making great pendulous masses of fine, feathery foliage, exceedingly graceful and beautiful. Grown in large pots or in hanging baskets, it makes one of the finest and most graceful plants that it is possible to imagine, and is one of the most useful plants for decorative purposes that has ever been grown. It is also valuable for cutting for use in fine cut-flower work. Extra fine plants, grown in 6-in. pots. very bushy. Ea. 75c. Large specimens, 8-in. pots, very fine. Ea. \$I.50.

\section{ASPIDISTRA.}

A. lurida variegata. Strong plants, 6-in., I6 to I8 leaves. Ea. \$2.00, doz. \$15.00. Greenleaved, 6-in. pots, I5 to I8 leaves. Ea. \$1.50, doz. \$15.00.

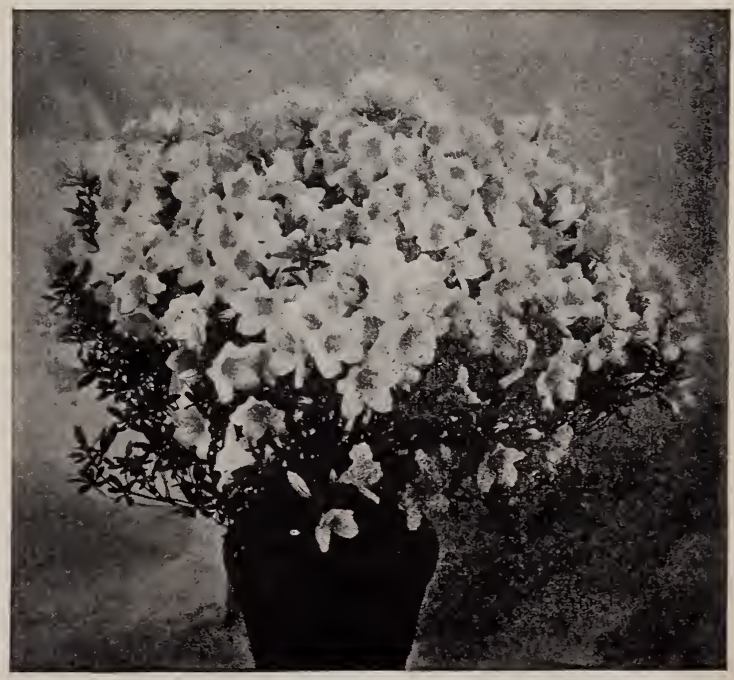

Azalea.

\section{AZALEAS.}

Our stock this season is the finest ever brought to this country. We personally selected the plants this Summer, having spent several weeks among the growers in Belgium, 
which enables us at this time to give our patrons the best varieties and finely shaped plants.

Per doz.

Io to I2 inches in diameter.......... \$7 50

I2 to I4 inches in diameter........... I0 00

I4 to 16 inches in diameter........... I5 00

I5 to 17 inches in diameter........... 2000

I6 to I8 inches in diameter............ 3000

I8 to 20 inches in diameter........... 4000

20 to 24 inches in diameter........... 5000

Special prices on quantities and large specimens. Write for List of Varieties.

\section{AZALEA MOLLIS.}

These are being used in large quantities for forcing and outdoor planting. Per doz. Per roo I2 to I5 inches high, well set

with buds................ \$4 $50 \quad \$ 3600$

I5 to I8 inches high, well set

with buds.............. $850 \quad 6000$

Write for special prices on large quantities, also standards, of which we have a large stock.

AZALEA PONTICA (Hardy Ghent).

Perfectly hardy. Our collection contains all the newest single and double varieties.

the ner doz.

I2 inch, IO-I5 buds.......... \$4 50 . \$3500

I5 inch, I5-20 buds.......... $650 \quad 5000$

If you want a large quantity, ask for special import catalogue.

We have thousands of Hardy Azaleas in our nurseries for outdoor planting. We will be pleased to give special prices on large quantities for this purpose.

\section{BEGONIA CREDNERI.}

We consider this the best introduction of recent years in ornamental flowering begonias. It is of strong, erect growth, producing naturally an elegantly shaped, symmetrically formed plant. The flowers are produced in large clusters on strong stems and are of the largest size. They are white, with a delicate suffusion of pink, making the flowers a decidedly pleasing color. The foliage is large, harmonizing beautifully with the other characteristics of the plant. The finest of flowering plants for house or greenhouse. Ea. 50c., doz. $\$ 4.50$.

\section{BEGONIA (Gloire de Lorraine).}

This new begonia exceeds in showiness any other variety. It is a Winter-blooming variety, flowering from October to May. It is of compact habit, and when in bloom produces a solid mass of brilliant pink flowers, completely covering the plant, making it a huge bouquet. Nothing that can be grown makes a finer show than this begonia. It is a novelty of sterling merit; we can recommend it in the very highest terms. 4-in. pots, per doz. $\$ 6.00 ; 5$-in. pots, per doz. \$12.00; 6-in. pots, per doz. $\$ 24.00$.

\section{BOSTON FERN.}

Nephrolepis Exaltata Bostoniensis.

5 -in pots, ea. 50c., per doz. $\$ 5.00$; 6 -in pots, ea. 75 c., per doz. $\$ 7.50 ; 8$-in. pots, ea. $\$ 2.00$, per doz. $\$ 20.00$.

\section{CAMELLIAS}

were at one time the queen of all flowers and are again becoming very useful and meeting with general favor. We have been fortunate in securing a large quantity in Europe, in all sizes and many varieties. Will be pleased to give any information on application.

\section{CHERRIES (Cerasus Chinensis).}

Japanese Pot-grown Plants. These have become the most beautiful of all Easterblooming plants; they produce pretty double pink flowers. Price ea. \$1.00, per doz. \$10.00.

\section{CIBOTIUM SCHIEDEI.}

This is undoubtedly the finest of all tree ferns for use in decorating. It will stand more rough usage than any of the other tree ferns. We offer fine plants in large size only; their fronds average from 2 to 4 feet long and I2 inches broad.

Size Height No of Leaves Each 8-in. pots.....24 to 28 in..6 to $7 \ldots \ldots \ldots$.... $\$ 600$

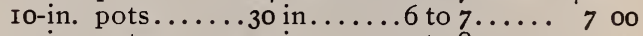
Io-in. pots...... 40 in...... 7 to $8 \ldots .$. . Io 00

\section{CROTONS.}

Nothing can excel the beauty and richness of coloring that is found in this class of plants. They are beautiful as pot plants for the conservatory, making handsome specimens for decorative and exhibition purposes, and are now used extensively as bedding plants, for which purpose they are exceptionally well adapted. They should be planted in full sun, in a position where they can be liberally supplied with water, which develops the most wonderful colorings in the foliage.

C. Andreanum. Deep green, with yellow and crimson markings.

C. Baron James de Rothschild. Olive-green and yellow, changing to brilliant crimson.

C. aureum maculatum. Long narrow foliage with numerous yellow spots.

C. Dayspring. Orange-yellow, edged with green and tinged with red.

C. Evansianum. Tricolored leaves, richly veined and mottled.

C. fasciatum. Rich green, with golden-yellow ribs and veins.

C. Interruptum. Peculiar twisted leaves with crimson rib.

C. Queen Victoria. Rich-golden yellow, mottled with green; mid-rib magenta changing to crimson.

C. rosea picta. Mottled yellow, crimson and green.

C. Sinitzianus. Long, narrow, graceful foliage; green, mottled yellow.

C. Veitchii. Bright green, marked and mottled with yellow and crimson.

C. Weismanni. Dark shining green, golden mid-rib and edges.

Ea. 75 c., doz. $\$ 9.00$.

We have a magnificent lot of fine specimens of Crotons, richly colored, upon which we will quote prices on application. 


\section{CYCAS.}

C. revoluta (Sago Palm). Dormant stems, 3 to 20 lbs. each, 100 lbs. \$15.00; less than 100 lbs., I8c. per lb.

\section{DEUTZIA GRACILIS.}

A fine lot of three-year-old plants suitable for 7 and 8 -in. pots; very bushy. Per doz. $\$ 2.50$.

\section{DEUTZIA LEMOINEI.}

This is now one of the standard varieties for forcing. It surpasses D. gracilis in its very large flowers, being nearly three times the size of the latter variety. These are produced in large, cone-shaped heads of 20 to 30 flowers each, and of the purest white. We are carrying the largest stock of these in the country, and offer strong one-year-old plants suitable for 6-in. pots, per doz. $75 \mathrm{c}$., per Ioo $\$ 6.00$.

\section{DRACÆNAS.}

D. amabilis. A strong growing variety, prettily variegated green, white and pale violet, turning to rose. Ea. \$1.oo.

D. Bruanti. A most useful variety, with heavy dark green foliage, making an excellent house plant, standing the dry atmosphere of living rooms. Ea. 5oc.

D. fragrans. A superb African species, with beautiful deep green leaves, lighter in the growth, though having no variegations or markings in the foliage. This is one of the most admired of the decorative species. Ea. \$1.00.

D. indivisa. This variety is used very extensively as a center plant for vases, urns, etc. It stands full exposure to the sun, and its long, narrow, graceful foliage contrasts beautifully with other foliage and flowering plants. Ea. 5oc. and \$1.oo.

D. Lindeni. A beatiful variegated form of fragrans, with broad green foliage and golden-yellow stripes on the edges of the leaves. Ea. \$1.00.

D. Massangeana. Another variegated form of the above with the variegation through the center of the leaf, instead of on the edges. Ea. \$1.0o.

D. Sanderiana. A graceful small-leaved variety, with glaucous green foliage, which is edged with a broad border of creamy white. Ea. $\$ 1.00$.

D. terminalis. Rich crimson foliage, marked with pink and white. Ea. \$1.0o.

\section{FICUS.}

F. elastica (Rubber Plant). We have a splendid stock of this useful and ornamental plant, which will flourish under the most adverse conditions. I2 to I5 in. high, ea. 50c.; doz. $\$ 6.00$; 15 to 18 in., ea. $75 \mathrm{c}$., doz. $\$ 7.50$; 24 to 30 in., ea. \$1.25.

\section{GARDENIA VEITCHII.}

This is the best variety for Winter flowering, being continually in bloom; large plants, ea. $\$ 1.00$, per doz. \$10.00.
HYDRANGEA HORTENSIA MARIESII.

This is, without doubt, the finest introduction ever made. It is so remarkable that one wonders why such an exquisite variety was not originated before. The sterile flowers are three inches in diameter and of a charming delicate pink, slightly suffused with a tint of mauve. It is certainly an entirely new form and will take the place of all existing kinds for pot culture and decorative purposes. 4-in. pots, ea. 50c., doz. $\$ 5.00 ; 5$-in. pots, ea. 75 c., doz. $\$ 7.50$.

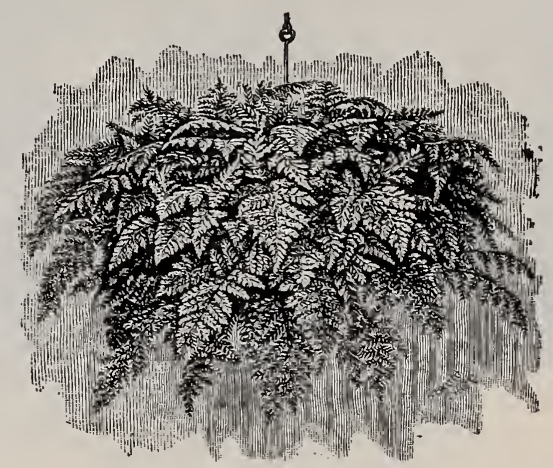

Japan Fern Balls.

\section{JAPANESE FERN BALLS}

(Davallia Bullata).

A variety from Japan, with deep green fronds 8 to Io inches long, from creeping rootstocks or rhizomes. These are made up by the Japanese as balls, and may be suspended from the roof of the conservatory or window garden, where they soon start into growth. These roots are fastened to a frame made of sphagnum moss, which retains the moisture, so that an occasional dipping into a pail of water is all that is required to keep the plants in a growing condition. Ea. 5oc. and $75 \mathrm{c}$.

\section{COLD STORAGE.}

Spiræa Astilboides floribunda for forcing. We put in cold storage last winter several thousand for this purpose. They are fine clumps and will be fine for Christmas. Per doz. $\$ 3.50$, per Ioo, $\$ 25.00$.

\section{CAMELLIAS.}

We have a fine lot of these in all sizes and many várieties. I 8 to 24 in., ea. $\$ I .00 ;$ doz. $\$ 9.00 ; 24$ in., ea. $\$$ I.5O; doz. \$15.00. Specimens, prices on application.

\section{NOVELTY 1903.}

New Begonia. Name will appear in our Spring Catalogue. Fine for bedding and pot purposes. 


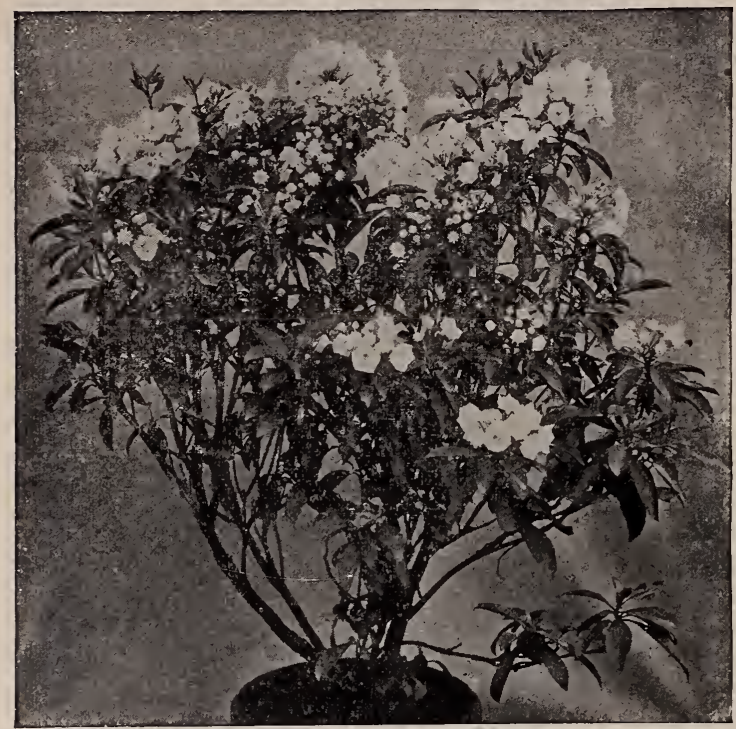

\section{KALMIA.}

K. Latifolia (Mountain Laurel, or Calico Bush). $5 \mathrm{ft}$. June. Broad, glossy green. shining foliage, flowers in large and showy clusters and of elegant shape, and most beautifully colored. Few broad-leaved evergreens are as beautiful in foliage, and none can excel the beauty and delicate form of its exquisite flowers. A native, but nevertheless, one of the finest ornamental shrubs in existence. I ft.. ea. 40c., doz. \$4.00. Larger plants, ea. $75 \mathrm{c}$., doz. $\$ 7.50$. Specimens. 3 to 4 ft., ea. $\$ 5.00$ to $\$ 7.50$.

\section{MANETTI STOCKS.}

We import large quantities, both English and French, especially for grafting greenhouse roses.

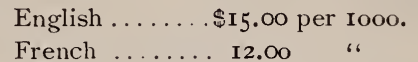

Kalmia Latifolia.

\section{LILAC FOR FORCING.}

We offer a fine lot of pot-grown plants, well set with buds and in fine condition for forcing, in following varieties: Mme. Lemoine, Ime. Casimir Perrier, Mme. Legraye, Chas. X., Louis Spaeth, M. Buchner, Leon Simon, ea. 75c., \$1.00, \$1.50.

\section{FRENCH FORCING LILACS.}

Large field-grown bushes. These have been grown especially for forcing, having been disbudded. They have long stems and will be valuable for cut flowers.

I 2 to 15 stems $\ldots \ldots \ldots \ldots \ldots \$ \mathbf{I} .50$ each.

25 to 30 " $\ldots \ldots \ldots \ldots \ldots, 3.00$ "

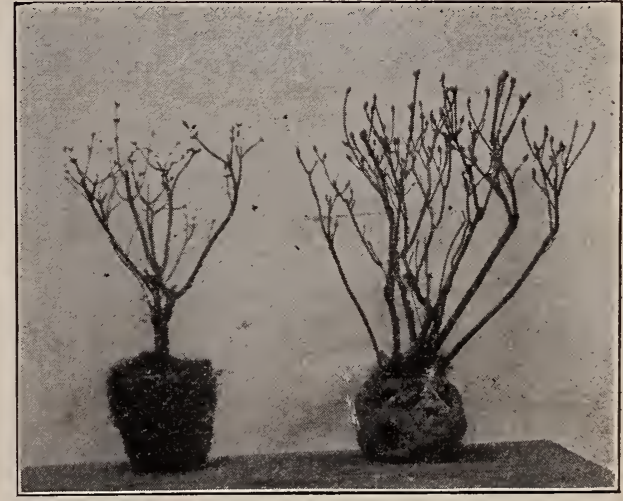

Dormant Lilac and Azaleas.

\section{THE HOME NURSERY.}

Gentlemen who intend planting large places will do well by writing for our special lists of small nursery stock. It is always advisable to make a limited-sized nursery to every country estate in order to have stock continually on hand for any kind of work that may have to be done. 


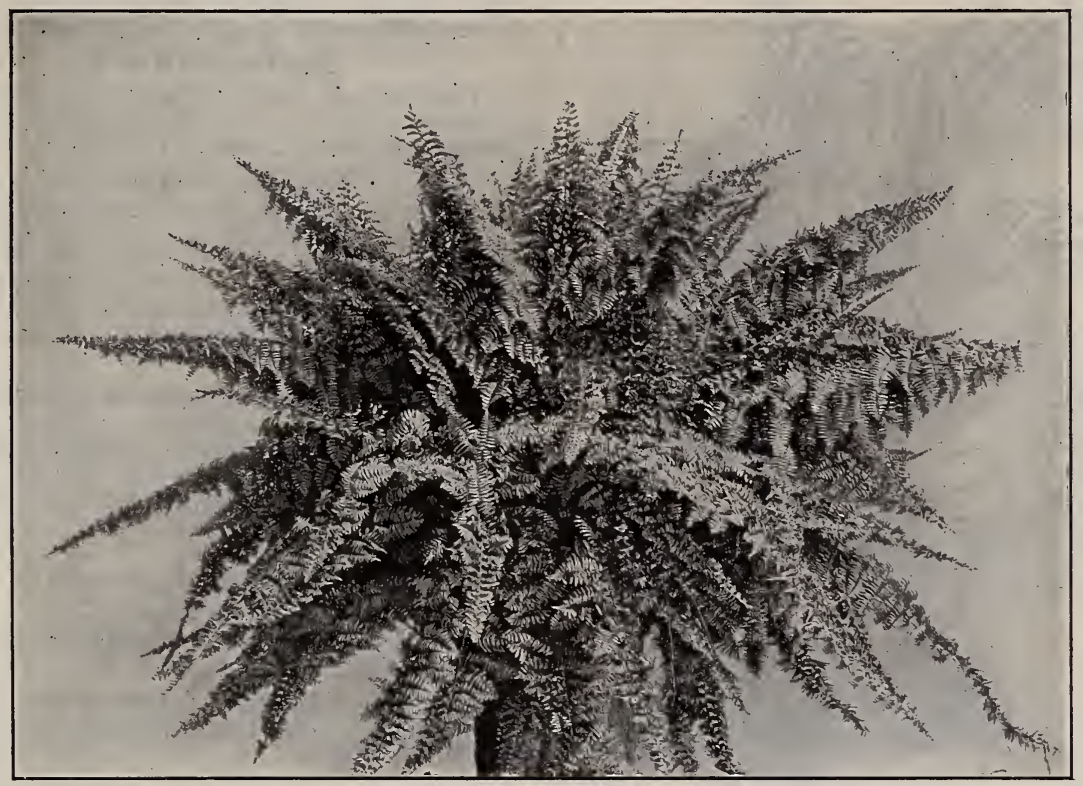

\section{NEPHROLEPIS PIERSONI.}

Prices on application for Spring Delivery.

\section{Shrubs, Trees, Evergreens, Plants, Bulbs, Palms, Feris, Orchids and Other Stock}

Not enumerated in this List can be supplied at the Lowest Market Cost.

Anyone desiring this stock will save money by submitting their lists of wants tor our lowest prices.

Parties filling conservatories, stocking greenhouses, or layirg out $\mathrm{n} \in \mathrm{W}$ grounds, will make money by consulting with us. IVe will call upon you by request and submit estimates.

......FOR ......

Ornamental Shade Trees, Hardy Climbers, Evergreeens, Hardy Plants, Conifers, Shrubs, Cannas, SEe OUR GeNeral and SPEcial catalogue. 


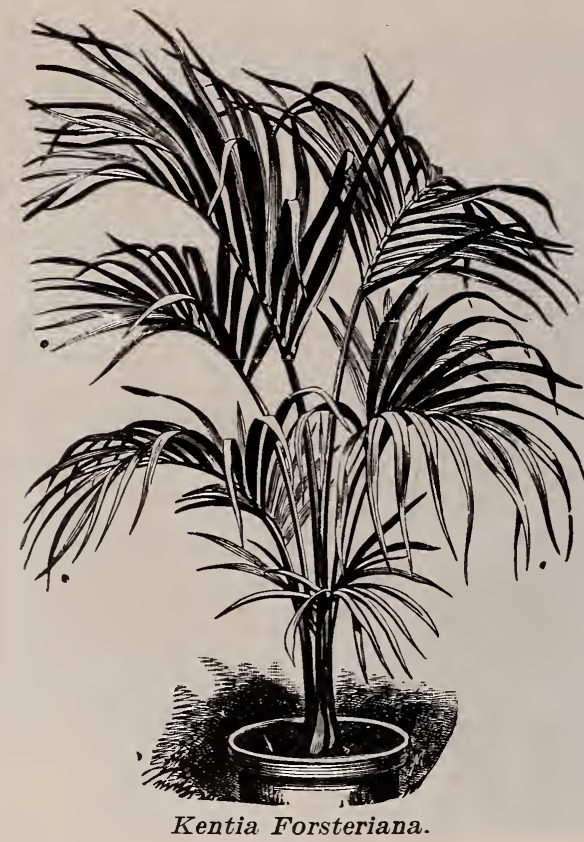

PALMS.

Kentias Belmoreana and Forsteriana. The Kentias are among the best of the palm species for general cultivation. Price, strong plants, 8-in. pots, ea. \$4.00; 7 -in. pots, ea. $\$ 3.00 ; 6$-in. pots, ea. $\$ 2.00 ; 5$-in. pots, ea. \$I.5o, doz. \$I5.00; 4-in. pots, ea. 75 c., doz. $\$ 7.50 ; 3$-in. pots, ea. 35c., doz. \$3.50. We have the largest stock of Kentias in the country. Ask for list with prices.

\section{PANDANUS.}

P. Veitchii. The leaves are light green, beautifully marked with broad stripes and bands of pure white, and most gracefully curved. One of the most satisfactory ornamental house plants. Fine plants, 5-in. pots, I ft. high, ea. \$I.50; 6-in. pots, I $1 / 2 \mathrm{ft}$. high, ea. $\$ 2.00$.

\section{PHCENIX RECLINATA.}

A fine decorative palm; one of the finest vase plants, particularly for outdoor decoration. It is of very robust habit, and is very easily grown. Will not burn under the hottest sun, and stands whipping by Summer storms without marring its beatuty. It is very effective when planted in earthen vases, and in this way is particularly ornamental for decorating court yards, verandas, etc. This is the palm that was used so largely in vases throughout the grounds of the Pan-American Exposition, the past Summer. It will thrive under more unfavorable conditions than any other palm, for which reason it is particularly adapted for hallways or other positions where other palms would not exist. We import large quantities every year. Large plants in Io-in. pots, $3 \mathrm{ft}$. high, ea. \$5.00; larger specimens, ea. $\$ 7.50$ to \$10.00. Extra specimens, ea. \$I5.00 to \$25.00.

\section{POMEGRANATE.}

A native of Asia and grown extensively in Southern Europe. Half hardy. We have some fine plants in 8-in. pots. Ea. \$2.50.

\section{RHODODENDRONS.}

Hardy and forcing kinds, in all best varieties. Per doz. Per 100

5 to 8 buds, 12 to I 5 in. high. . \$9 oo $\$ 5000$ 6 to Io buds, I5 to I8 in. high. . I 2 oo 7500 Io to I 5 buds, I8 to 24 in. high.. I5 00 I00 00 Specimens, $\$ 2.00$ to $\$ 10.00$ ea.

Write for list of varieties.

TREE FERNS (Dicksonia Antarctica).

We have at our disposal a large quantity, in all sizes, of this most graceful fern. They are particularly desirable for decorative purposes for large halls and conservatories. We will be pleased to give sizes and prices on application.

\section{VIBURNUM PLICATUM (Japanese Snowball).}

We have a fine lot of pot-grown plants for forcing. Ea. \$1.00, doz. \$10.00.

\section{WISTARIA CHINENSIS.}

Handsome pot-grown plants; well budded. Ea. \$I.50, doz. \$12.00.

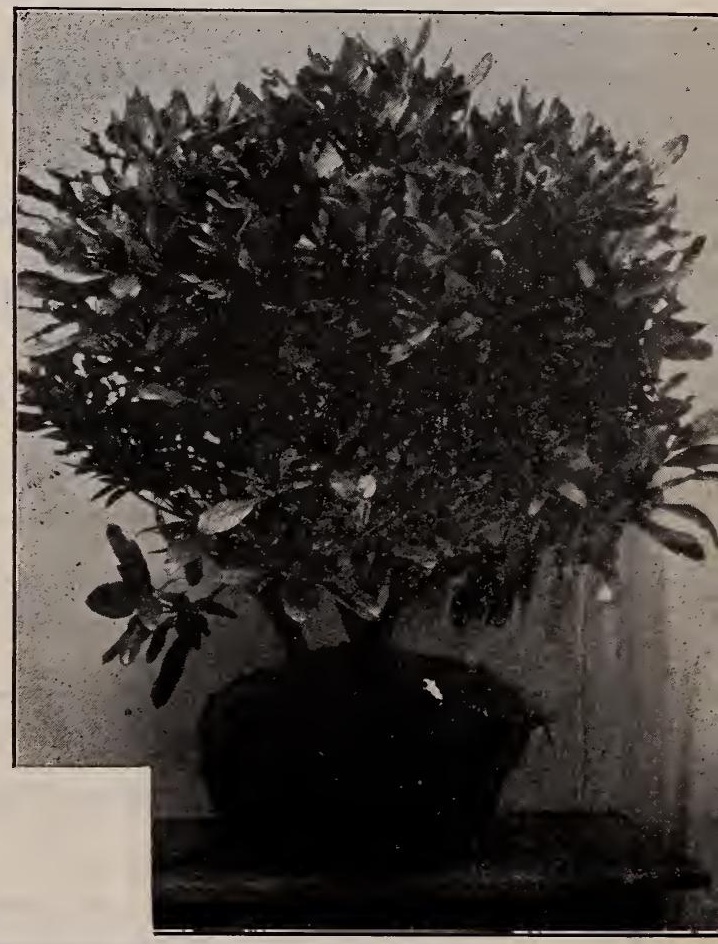

Rhododendrons as Imported. 


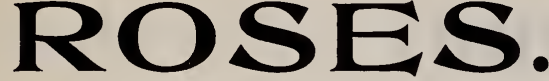

We are Headquarters for

HARDY HYBRID PERPETUAL ROSES.

We have a very select list of varieties, constituting the best for every purpose, 2 years old, strong field grown.

Per doz. Per 100 Per 1000

Buyers' choice.......\$3 oo \$18 o0 $\$ 12500$

Our choice............2 50 I5 00 IIO 00

Write for List of Roses.

EVER-BLOOMING or MONTHLY ROSES.

Clothilde Soupert, White Maman Cochet, Maman Cochet, Hermosa, Agrippina, Kaiserin Augusta Victoria, and many other varieties.

Don't fail to visit our nurseries and inspect our Tea Roses in bloom in the field.

\section{STANDARD OR TREE ROSES.}

We have at last overcome the trouble of the frost killing the stems, and now graft on Rosa rugosa and cinnamomea stocks. We have several thousand of these on hand in the finest and most popular varieties.

Hybrid Perpetual Varieties, Named Sorts, ea. 50c., Io for $\$ 4.50$.

Crimson Ramblers. These make attractive plants when grown in standard or tree form. The large plants make magnificent specimens, and when in full bloom are the most attractive. Nothing is so well adapted for growing in this form as the beautiful Crimson Rambler. Ea. 6oc., Io for \$5.00. All our stock is strong and healthy, and will give immediate results.

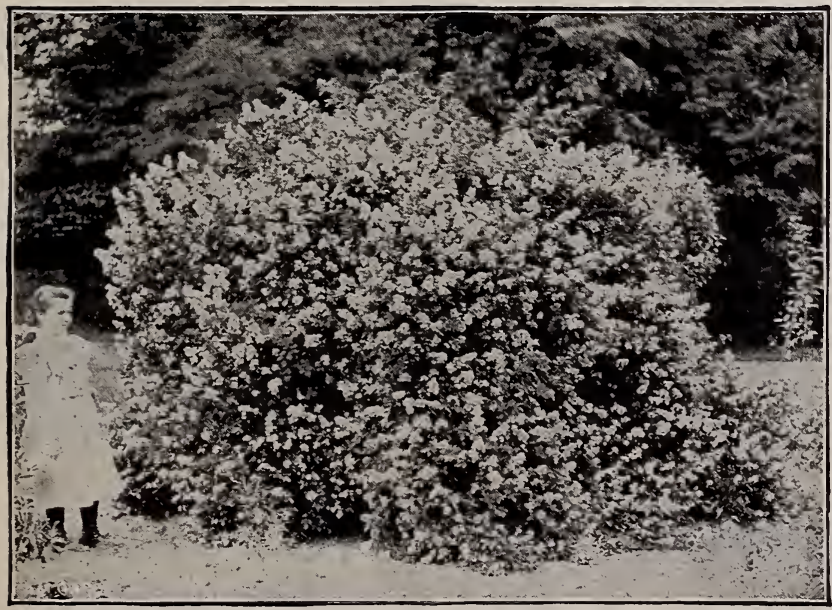

Rosa Multiflora Japonica.

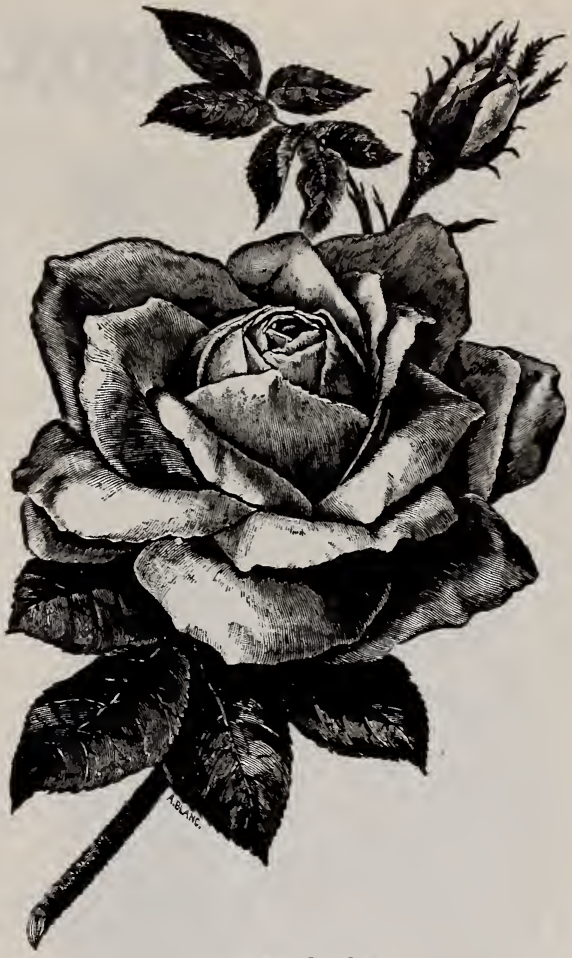

Maman Cochet.

\section{ROSA MULTIFLORA JAPONICA.}

This beautiful Japanese rose has now become so popular on account of its usefulness that all landscape gardeners and florists are using it for outdoor planting. One-year-old plants, $\$$ r.oo per doz.; \$5.00 per 100; $\$ 40.00$ per rooo.

NEW WICHURAIANA ROSE.

The B. \& A. Double Pink Memorial Rose. There is nothing in roses introduced in recent years that has proved such an innovation, or so valuable as the Japanese trailing Rosa Wichuraiana, or the Memorial Rose. This variety is a seedling from Wichuraiana, carrying with it all its beautiful characteristics in every respect, with the exception of the flowers, which are very double, 2 to $2 \frac{1}{2} \mathrm{in}$. in diameter, and are of the brightest and most cheerful rosy pink. Its fragrance is delightful, being distinct from that of any other rose. 2 -in. pots, ea. $25 \mathrm{c}$, doz. $\$ 2.50$, $100 \$ 15.00$. Strong field-grown two-year-old plants, ea. $75 \mathrm{c}$, , doz. $\$ 8$. 00 . 


\section{BOXWOOD.}

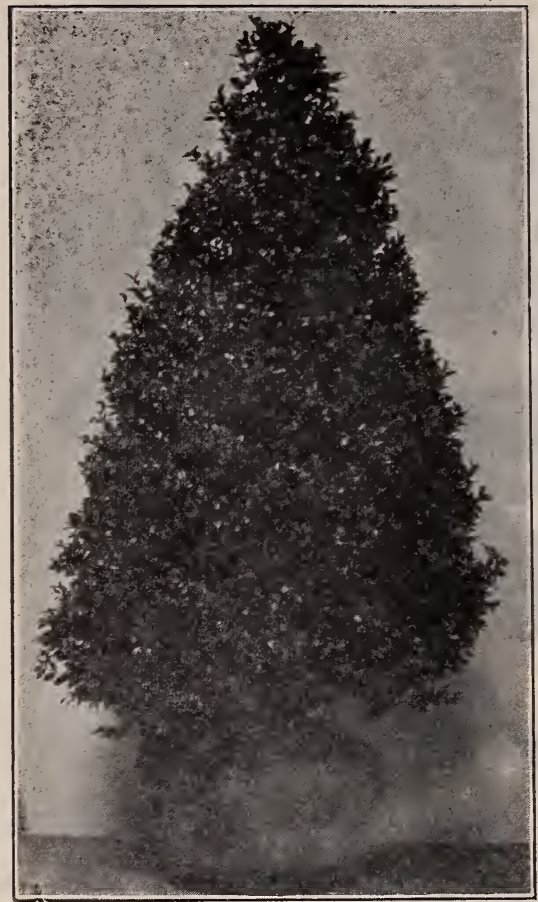

Prramid Boxwood.

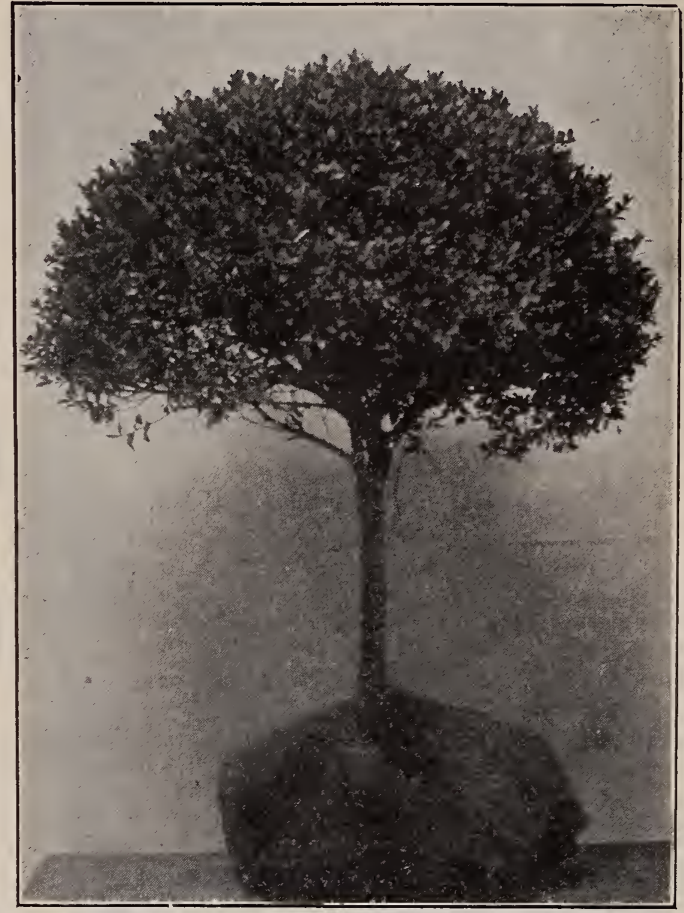

Standarl Boxwood.

The different species vary in size from low bushes to medium sized trees. All are long-iived. hardy, of dense, compact growth, and have dark green glossy leaves. They are used for grouping, edging walks, planting against house foundations, for hedges, and in tubs for formal gardens, terraces and porches. Will grow in sun or shade, preferably the latter. Our stock is clipped to fine broad-conical form, but have also imported a fine lot of natural growth bushes.

While in Europe this Summer we selected several hundred very fine specimens; we will be pleased to give prices upon application.

We have many to sell of the following sizes: Pyramids,

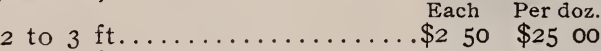

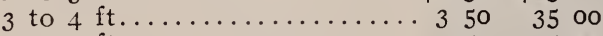

4 to $5 \mathrm{ft} \ldots \ldots \ldots \ldots \ldots \ldots \ldots \ldots 450 \quad 45$ oo

Stock arrives about October Ist.
}

Standards,

Each Per doz. I8 to 24 in., diameter of head. $\$ 2 \quad 50 \quad \$ 2500$ 24 to 39 in., diameter of head. . 4 o0 4500 30 to 36 in., diameter of head.. $750 \quad 7500$ Write for further particulars.

We have been fortunate in securing a very fine collection of Evergreens and Clipped Boxwood grown in Holland. Anybody interested in choice stock will do well by writing us for particulars.

\section{BOXWOOD EDGING.}

We have 250,000, eight to twelve inch size. Per 100, $\$ 5,00$; per 1000, $\$ 40.00$. Special quotation on large sizes. 


\section{FOREIGN GRAPE VINES.}

(Pot Grown).

Owing to the scarcity of American-grown stock, we have arranged with one of our European growers for a supply. While the price may appear high, the strength, size and quality of stock is so much superior that comparison cannot be made with the light canes usually sent out. We offer twelve varieties, but will be pleased to furnish a list of other sorts that can be supplied.

Please place your order at once. Strong two-year-old, ea. \$3.00, doz. \$35.00. Selected $x x x$ fine, ea. $\$ 5.00$, doz. $\$ 50.00$.

\section{BLACK VARIETIES. \\ Selected Canes, ea. \$5.00.}

Alnwick Seedling. An excellent late variety.

Black Alicante. Bunches medium, berries very large lots.

Black Hamburg. The most useful and popular grape.

Gros. Colmar. A very handsome grape, berries and bunches of enormous size.
Lady Downe's Seedling. Flesh firm and sweet; one of the best late grapes and an excellent keeper.

Muscat Hamburg. An excellent and richly flavored grape.

Madresfield Court. Berries very large; of rich flavor.

\section{WHITE VARIETIES.}

Muscat of Alexandria. Flesh firm and rich, berries large; a superb variety; requires heat to ripen.

Cannon Ball Muscat. Is the most profitable and striking amber-colored grape in existence. It makes enormous berries of a delicious flavor; the bunch is large and well-shaped.

Golden Hamburg. A beautiful golden variety, rather early, oval berries of large size and most delicious flavor.

Boxwood Muscat. Very large oblong berries, of a pretty golden yellow color. A delicate musk flavor; good keeper.

Foster's White Seedling. A fine grape; very sweet flavor.

\section{Evergreen and Coniferous Trees.}

\section{CALI, AND INSPECT OUR STOCK.}

A most beautiful effect may be produced by planting evergreens of moderate growth in beds, care being taken to select varieties which contrast in color. The advantages resulting from planting of evergreens are many, and no grounds are complete without them. They retain their beauty not only through summer's heat, but through winter's cold.

Again we call attention to our large and varied stock of evergreens, and to the advisability of their being more generally planted. The increase in value of property ornamented in this way, and the benefits derived from having buildings protected from winter's storms by belts or large clumps of evergreens, are many. Every one notices and admires the cheerful and comfortable appearance of the homes of the thrifty, who have improved their grounds, and property always commands higher prices in consequence of such improvement. A garden sheltered by evergreen hedges will produce vegetables one to two weeks earlier than an open field.

If those who wish to plant will correspond with or call on us, we will offer inducements on certain varieties in quantity. We recommend spring planting for evergreens.

We give below a list of the best conifers, and embrace such varieties as can stand any climate, and at the same time varieties of great value.

Our conifers have been transplanted several times, having a good ball and an abundance of fibrous roots. On account of the limited space in our catalogue we are unable to give a complete list of varieties we carry. Same can be had on application.

\section{Section 1. ABIES. Spruce and Hemlock.}

A. amabilis (Lovely Silver Fir). Fine glaucous foliage. Ea. $\$ 3.00$ to $\$ 6.00$.

A. balsamea (Balm of Gilead Fir). Very hardy; foliage silvery underneath. Ea. 50c. to $\$ 1.00$.

A. cephalonica glauca. Very distinct. Ea. $\$ 2.50$.
A. concolor (Concolor Spruce.) One of the hardiest and most beautiful Evergreens. Tree of graceful, stately habit. Large, broad, silvery green foliage. A rare and exccedingly choice variety. Ea. $\$ 2.00$ to $\$ 5.00$.

A. concolor violacea. Foliage blue; very fine variety. Ea. $\$ 4.00$ to $\$ 6.00$.

A. Douglasii glauca. Foliage glaucous. Ea. $\$ 2.50$. 


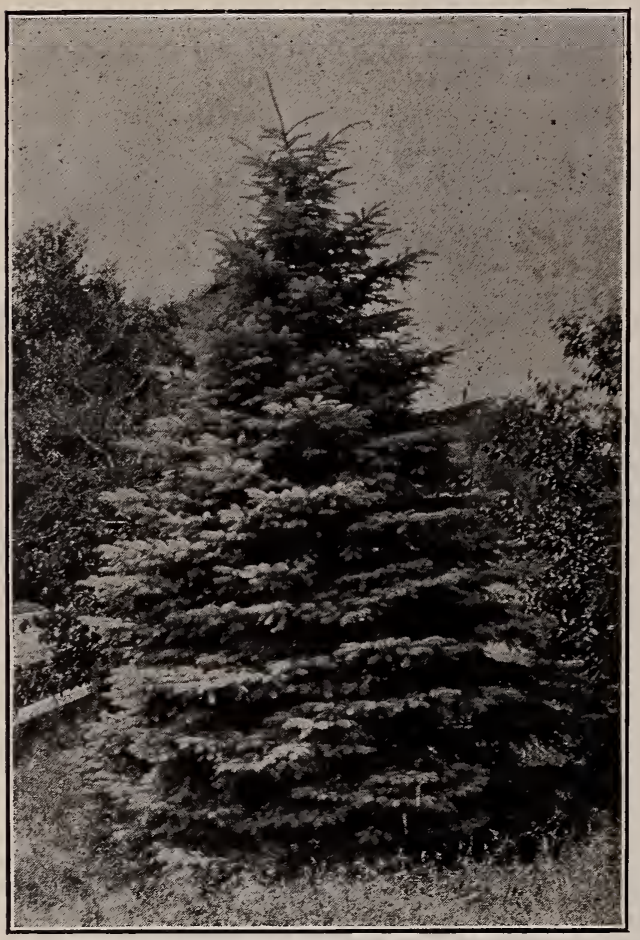

Picea Pungens Glauca (Blue Spruce).

A. lasiocarpa. Bluish-green foliage, long needles, spreading habit, very distinct. Ea. $\$ 3.00$ to $\$ 5.00$.

A. 1. argentea. A silvery variety of the above. Ea. $\$ 3.00$ to $\$ 5.00$.

A. magnifica. Slow but beatiful grower; bluish foliage; extra fine evergreen. Ea. \$2.50 to $\$ 5.00$.

A. m. glauca. Ea. $\$ 2.50$ to $\$ 5.00$.

A. nobilis glauca. Beautiful variety; foliage blue. Ea. $\$ 3.00$ to $\$ 10.00$. Extra large specimens, ea. $\$ 10.00$ to $\$ 25.00$.

A. Nordmanniana (Nordmann's Silver Fir). Medium size, but of symmetrical form and majestic growth. Horizontal branches with large, massive, dark green foliage, glaucous underneath, producing a rich and delicate effect. Ea. \$I.Oo to \$2.50. Specimens, ea. $\$ 5.00$ to $\$ 10.00$.

A. numidica. Very fine, dark foliage. Ea. \$2.50 to $\$ 4.00$.

A. pectinata (Silver Fir). Ea. $75 \mathrm{c}$.

A. p. pyramidalis. Very fine. Ea. $\$ 2.00$ to \$4.0o.

A. p. pendula (Weeping Silver Fir). Rare and unique variety of distinct habit. Ea. \$1.00 to $\$ 3.00$.

A. pinsapo. Handsome variety; branches very thick, compact but horizontal growth. Ea. $\$ 2.00$ to $\$ 3.00$.
A. p. glauca. New. Foliage glaucous; very rare. Ea. $\$ 2.00$ to $\$ 5.00$.

A. umbilicata. Ea. $\$ 2.00$ to $\$ 5.00$.

A. Veitchii (Veitch's Silver Fir). A very rare and beautiful species, partaking of the character of nobilis and of Nordmanniana. Ea. \$3.00.

\section{Section 2. PICEA. Silver Fir.}

P. alba (White Spruce). Fine compact, pyramidal form, moderate growth, foliage silvery gray and light-colored. Suited to the seashore. A valuable evergreen more compact and symmetrical than the Norway Spruce. Ea. $75 \mathrm{c}$.

P. a. aurea (Glory of Spruces). Golden tinted foliage; fine. Ea. $\$ 3.00$ to $\$ 5.00$.

P. Alcockiana. Foliage light blue beneath and dark green above; of pyramidal and moderate growth; very interesting tree. Ea. \$I.25, \$I.5O and \$2.50.

P. Engelmanni. Resembles the Pungens; compact, fine for lawns; pyramidal form; branches sometimes pendulous, foliage with a rich silver sheen. A very valuable and hardy tree. Ea. \$1.00 to \$2.00.

P. excelsa (Norway Spruce). 21/2-4 ft. Ea. 50c., doz. $\$ 5.00$

P. e. aurea (Golden Norway Spruce). Ea. \$I.50 to $\$ 2.50$. Specimens, ea. $\$ 5.00$ to $\$ 10.00$.

P. e. compacta (Compact Spruce). Dense and distinct; foliage light green. Ea. \$I.00 to $\$ 2.00$.

P. inverta (Pendulous-branched Spruce). A pendulous variety of the Norway Spruce, with larger and brighter foliage than that of the species. The lateral branches of the large trees are as drooping as a Willow. $\mathrm{Ea}$. \$3.00 to \$5.00. Specimens, ea. \$10.00.

P. Menziesii (Menzies' Spruce). Slow growth; pyramidal form; thickly branched, having a silvery appearance; prickly leaves. Ea. $\$ 2.00$ to $\$ 4.00$.

P. Mercki. Compact grown; very distinct. Ea. $\$ 1.00$ to $\$ 3.00$.

P. Morinda (Himalayan Spruce). Foliage light glaucous green; vigorous grower. Ea. $\$ 1.50$ to $\$ 2.50$.

P. orientalis (Oriental Spruce). Dark shining green foliage; very fine. Ea. $\$ 2.00$ to $\$ 3.50$.

P. o. pygmæa. Compact growth. Ea. $\$$ I.0o to $\$ 2.00$.

P. polita (Tiger's Tail Spruce). Pointed light green leaves. Ea. \$I.00 to \$3.50.

P. pungens (Colorado Spruce). Ea. $\$ 2.00$ to $\$ 3.00$.

P. p. glauca (Colorado Blue Spruce). Grafted from selected specimens only. Ea. \$2.50 to $\$ 5.00$ Large specimens from $\$ 7.50$ to $\$ 25.00$ ea.

P. remontii. A beautiful dwarf form of P. excelsa, slightly inclined to fastigiate shape; compact and very hardy. Ea. $\$ 2.00$ to $\$ 3.00$.

TSUGA canadensis (Common Hemlock). Transplanted trees; $3 \mathrm{ft}$. Ea. \$1.0o, doz. $\$ 10.50$. Extra fine specimens from $\$ 5.00$ to $\$$ Io.0o ea. 


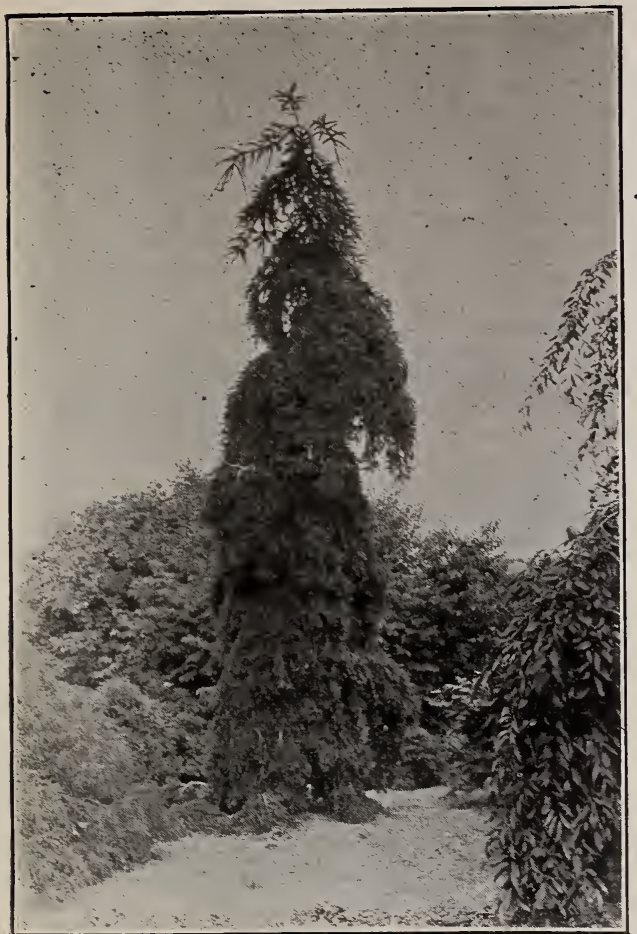

Picea Excelsa Inverta.

T. Hookeriana (Hooker's California Spruce). A rare and beautiful hardy variety somewhat resembling the Hemlock in growth; pale blue-green foliage, thickly set on the branches. Ea. \$I.oo and \$I.50.

CEDRUS atlantica glauca. One of the most beautiful evergreens yet sent out. Upright growth, but low branched and of compact habit, with solid foliage entirely covering the branches. Leaves very fine and of a delicate steel-blue tint, equal to the finest of the glaucous Colorado Blue Spruce. Perfectly hardy in northern Europe, and should succeed where the Retinosporas do well. A great acquisition to the list of choice Coniferæ. Very rare. Ea. $\$ 5.00$ to \$I 5.00.

C. Deodara (Deodar or Indian Cedar). Of vigorous growth; pyramidal form; graceful foliage of a light, silvery or gla ucous green. One of the most beautiful of evergreens; not entirely hardy north of New York. Ea. $\$ 2.50$ to $\$ 5.00$. Extra specimens, prices on application.

CEPHALOTAXUS drupacea. Forms a beat1tiful low bush, with stiff spreading branches of light green. Ea. \$3.00 to \$5.00.

C. Fortunei. Medium size, rounded form; foliage dark green; long slender branches. Ea. $\$ 2.00$ to $\$ 5.00$.

\section{CUPRESSUS (Cypress).}

C. Lawsonii. Ea. $\$ 1.00$ to $\$ 5.00$.

C. erecta viridis. Fine upright growth. Ea \$2.00.

C. Fraseri. Dark green foliage. Ea. \$2.50 to $\$ 4.00$.

C. alumi. One of the hardiest varieties. Ea. $\$ 2.00$ to $\$ 3.00$.

C. Lawsoniana filifera glauca. A splendid addition to the Conifers. This variety was found amongst a bed of seedlings and took our special attention through its fine growth. The branches are thin, like thick needles, and hang gracefully down, while they have a dark greenish-blue color. It is a strong grower. Ea. $\$ 2.50$ to $\$ 4.00$.

\section{JUNIPERUS (Juniper).}

J. alba variegata (Silver variegated Juniper). Variegated glaucous green and pure white foliage. Distinct and fine. Ea. \$1.0o to $\$ 2.50$.

J. canadensis aurea (Golden Juniper). Low form; foliage solid golden yellow; very permanent and distinct. The choicest Golden Conifer. Very effective planted in masses. Ea. \$1.00 to \$3.00.

J. aurea prostrata. Dwarf trailing variety; spreading habit. Ea. \$I.0o to \$I.50.

J. chinensis (Chinese Juniper). One of the most desirable, forming a handsome, dense shrub, with branches somewhat pendulous and dark green foliage. Ea. \$1.0o to \$2.50.

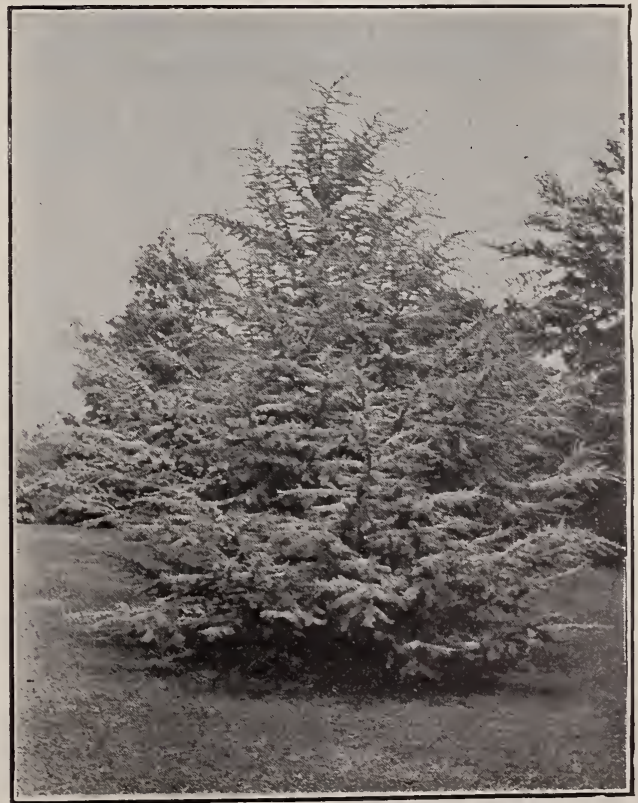

Cedrus Atlantica Glaucus. 
J. c. aurea (Golden Chinese Juniper). One of the finest evergreens; spreading habit and beautiful gold-marked foliage. Ea. \$I.50 to $\$ 3.00$.

J. hibernica (Irish Juniper). A distinct and beautiful variety, of erect, dense conical outline, resembling a pillar of green; very desirable. Ea. $75 \mathrm{c}$. to $\$ 3.00$.

J. sabina (Common Savin Juniper). Low, trailing habit and fine for massing. Ea. 5oc.

J. s. tamariscifolia (Gray Carpet Juniper). A distinct trailing variety of Sabina. Ea. 75c.

J. Schottii. Hardy and beautiful, forming a dense bush. Foliage light green. Ea. \$1.00 to $\$ 2.00$.

J. sphærica. Very distinct; blue color. Ea. $\$ 1.50$ to $\$ 2.50$.

J. virginiana (The Common Red Cedar). Of medium compact growth; varies considerably in habit and color of foliage; leaves a bright green. Ea. 25c. to 50c.

J. v. alba spica (Variegated Red Cedar). The same as the preceding, with branchlets of creamy white interspersed among the green. Ea. $\$ 1.50$ to $\$ 2.00$.

J. v. elegantissima (Golden Cedar). Beautiful golden brown foliage; effective in winter growth; distinct. Ea. $\$ 1.50$ to $\$ 2.50$.

J. v. glauca (Silvery Red Cedar). Fine vigorous grower, cone shaped, and having a peculiar whitish color. Ea. \$I.50 to \$2.50.

J. v. pendula (Drooping Red Cedar). Ea. $\$ 2.00$ to $\$ 4.00$.

J. v. plumosa argentea (Variegated Red Cedar). Ea. $\$ 1.50$ to $\$ 3.00$.

\section{LARIX LE H TOLEPSIS (Money Pine of Japan).}

Most vigorous grower of all the Larches; slender, dark yellowish ash colored branches; rich green foliage. We have a fine stock of same grown in pots, 5-6 ft. Ea. $\$ 5.00$.

L. europæa (European Larch). The common variety. Ea. 25c. to 50c.

L. Kæmpferi (FromJapan). Foliage a light green, turning to a golden yellow in fall. Ea. \$1.oo.

L. pendula (Weeping European Larch). A very unique and beautiful small tree, making an effective object in landscape. Foliage like common variety, large and of rich color. Ea. \$2.50 to \$5.00.

LIBOCEDRUS Decurrens (Syn. Thuja gigantea). Ea. $\$ 3.00$ to $\$ 5.00$.

\section{RETINOSPORA.}

R. ericoides. Compact growth; very effective on account of its colors turning from violet to green in winter. Ea. $35 \mathrm{c}$. to $75 \mathrm{c}$.

R. e. aurea. See Novelties.

R. filifera. Thread-branched, drooping branches, bright green; very pretty. Ea. \$I.50 to $\$ 5.00$. Large specimens, ea. $\$ 10.00$ to $\$ 25.00$.

R. f. aurea. Golden; most attractive. (New.) Ea. $\$ 4.00$ t๑ $\$ 6.00$.
R. leptoclada. Very dark foliage. Ea. $\$ 2.50$ to $\$ 3.50$.

R. obtusa. Dark foliage; compact growth. Ea. $\$ 1.00$ to $\$ 2.50$.

R. o. filicoides. Fern-like foliage. Ea. \$3.00.

R. o. gracilis. Ea. \$2.50.

R. o. nana (Dwarf Japanese Retinospora). Very dwarf; seldom attains a height of $3 \mathrm{ft}$. Ea. $\$ 2.50$ to $\$ 5.00$

R. o. nana aurea (Golden Dwarf Obtuse Retinospora). Rich bronze-yellow leaves. Ea. $\$ 1.50$ to $\$ 5.00$.

R. plumosa. Ea. 50c. and $75 \mathrm{c}$. to $\$ 5.00$. Fine large speciniens, ea. $\$ 7.50$ to $\$ 25.00$.

R. p. argentea (Silver Plume-like Retinospora). Silver-tipped foliage. Ea. \$1.0o to \$3.00.

R. p. aurea. Golden variety; foliage yellow. Ea. 50c. and $75 \mathrm{c}$. to $\$ 5.00$. Fine large specimens, ea. $\$ 7.50$ to $\$ 25.00$.

R. p. lutea nova. (New). B right sulphur color, of great effect. Ea. $\$ 2.00$ to $\$ 5.00$.

R. p. lutescens. Verv compact form; beautiful golden leaves; ball-shape growth. Ea. \$1.00 to $\$ 3.50$.

R. pisifera. Feathery foliage; dark green. Ea. $\$ 1.00$ to $\$ 2.50$.

R. p. aurea. Golden feathery foliage. Ea. $\$ 2.00$ to $\$ 2.50$. Specimens, ea. $\$ 5.00$ to $\$ 10.00$

R. squarrosa Veitchii. Light bluish green foliage; very dense growth. Ea. 50c. and $\$ 1.50$ to $\$ 3.50$. Large specimens, ea. $\$=.00$ to $\$ 10.00$.

R. s. V. glaucescens. As former variety; better color. Ea. \$1.50.

\section{PINUS (Pine).}

P. austriaca (Austrian Pine). A robust stately tree of rapid growth, and very hardy. Stiff, long, dark green leaves. Valuable for general planting. Ea. 35c. to $\$ 1.00$.

P. Cembra. Bluish foliage. Ea. \$1.50 to \$3.00.

P. excelsa (Lofty Bhotan Pine). One of the most beautiful and valuable of hardy evergreens. Long, rich, silver foliage, gracefully pendulous. Rart. Ea. 75c. to \$I.50.

P. Mughus (Dwarf Mugh) Pine). Very distinct. Ea. \$1.00 to \$2.00.

P. parviflora glauca. (New.) Ea. $\$ 5.00$ to $\$ 10.00$.

P. strobus (White Pine). One of the best native pines; pale light-green foliage. Hardy and valuable. Ea. 35c. to \$I.oo.

P. sylvestris (Scotch Pine or Fir). A native European species of rapid growth, with strong branches and short stiff bluish-green foliage. Ea. 50c. to \$1.00.

PODOCARPUS coreanus (Japan Yew). An upright, very slow-growing tree; dark leaves. Ea. $\$ 3.50$ to $\$ 7.50$. Extra fine specimens, ea. $\$ 15.00$ to $\$ 20.00$.

PSUEDO-TSUGA Douglasii (Douglas' Spruce). Large, conical form, smooth bark; branches numerous, irregularly placed along the stem, spreading, horizontai, sometimes a little ascending; leaves light green above, glaucous below. Ea. \$I.oo. 
SCIADOPITYS verticillata (Umbrella Pine). A very odd tree from Japan, and unlike anything before known in hardy trees or plants. Very long leaves, much wider than those on other Coniferæ, shining green above and a line of white underneath. The horizontal branches and peculiar growth of the leaves in parasol-like whorls gives the variety a very distinct individuality. Ea. $\$ 4.00$ to $\$ 6.00$. Large specimens, ea. \$10.00 to $\$ 25.00$.

\section{TAXUS (Yew).}

T. baccata (English Yew). Bushy, dark foliage. Ea. \$1.50 to \$2.50. Specimens, ea. $\$ 5.00$ to $\$ 10.00$.

T. b. adpressa. Ea. \$1.50.

T. b. aurea. Golden. Ea. $\$ 2.50$ to $\$ 5.00$.

T.b. erecta. Fine variety. Ea. \$1.50 to $\$ 3.50$.

T. b. Dovastoni aurea. Ea. $\$ 3.00$ to $\$ 5.00$.

T. b. D. pendula. Ea. $\$ 5.00$ to $\$ 10.00$.

T. b. elegantissima (Variegated Yew). Very pretty: rare. Ea. $\$ 3.00$ to $\$ 7.50$. Specimens, ea. \$10.00 to \$15.00.

T. b. fastigiata. A valuable variety, of very upright growth; : deep blackish green foliage. Ea. $\$ 3.00$ to $\$ 5.00$.

T. b. f. aurea. Foliage handsome green, bordered with yellow. Ea. $\$ 3.00$ to $\$ 10.00$.

T. b. f. lutea novea. The finest golden of all Yews. Ea. $\$ 5.00$ to $\$ 7.50$.

T. b. f. Washingtonia. Fine golden foliage; handsome and rare. Ea. \$3.00 to \$4.0o.

T. hibernica (Irish Yew). Pyramidal upright growth; very dark foliage; slow grower; very attractive on lawns. Ea. $75 \mathrm{c}$. to $\$ 5.00$. Large specimens, ea. \$10.00 to \$I 5.00.

T. h. aurea (Golden Irish Yew). Leaves green in the center, and margined with yellow. Ea. $75 \mathrm{c}$. to $\$ 5.00$. Large specimens, ea. $\$ 10.00$ to $\$ 15.00$.

\section{THUJA (Western Arbor Vitae).}

T. Lobii. Brilliant dark green Conifer, hardy and vigorous. Ea. $\$ 2.00$ to $\$ 3.00$.

T. L. aurea. Same as Thuja Lobii, but with dark green foliage; true. Ea. \$2.50 to \$4.00.

T. L. aurea variegata. New. Ea. \$5.00.

T. occidentalis (Common American Arbor Vitæ). Ea. 25c. to 50c. Low rates per 100.

We have some fine specimens 6 to $8 \mathrm{ft}$. high: Ea. $\$ 3.00$ to $\$ 6.00$.
T. o. Columbia. A new variegated variety; strong habit; foliage broad, with a beautiful silver variegation. Ea. \$1.00 to \$2.00.

T. o. cristata (Crested Arbor Vitæ). Branches growing close together, with deep green foliage, the ends drooping and crested. Ea. 75 c. to $\$ 3.50$.

T. o. Elwangeriana. $2 \mathrm{ft}$. Ea. \$1.0o.

T. o. globosa (Globose Arbor Vitæ). Round, compact form and dense foliage. Ea. 5oc. to $\$$ I.50.

T. o. Hovey dwarf (Globe shape). Ea. इoc. to $\$ 3.00$.

T. o. lutea. Variety of the well-known Nootka Sound Cyoress, having a clean yellow foliage in its terminal branches. Hardier than its parent. Ea: $\$ 1.00$ to $\$ 5.00$.

T. o. plicata (Nootka Sound Arbor Vitæ). A fine hardy variety. Ea.. \$2.00 to \$3.00.

T. o. pyramidalis (Pyramidal Arbor Vitæ). A most valuable upright evergreen of dense, compact habit. Foliage light green. Columnar form, similar to Irish Juniper or Erect Yew. Ea. \$2.00 to \$4.00.

T. o. Rosenthalii. Ea. \$1.00 to \$2.50.

T. o. species Rivers. Bright green variety. Ea. $\$ 2.00$ to $\$ 3.00$.

T. o. sibirica (Siberian Arbor Vitæ). Ea. 50c. to \$1.oo.

T. o. spicata alba. Ea. $\$ 2.00$ to $\$ 3.00$.

T. o. Vervæneana. Ea. $\$ 2.00$ to $\$ 5.00$. Extra fine specimens, ea. $\$ 7.50$ to $\$$ Io.oo.

T. o. Warreana. Very hardy. Ea. \$1.oo to $\$ 5.00$.

T. o. W. lutescens. Ea. $\$ 3.00$ to $\$ 5.00$

THUYOPSIS borealis, syn. Cupressus nutkænsis (Nootka Sound Thuyopsis). Of vigorous, erect growth; sDreading branches, drooping at the ends, of a silvery glaucous tint. Ea. \$1.50 to \$3.00.

T. b. dolabrata. Exceedinglv beautiful, horizontal branches, slightly pendulous, flat leaves. Ea. \$1.00 to $\$ 2.50$

T. b. d. variegata (Variegated Thuyorsis). Attractive foliage, of a bright green color above and silvery white underneath. Ea. $\$ 2.00$.

T. Standishii. $2 \mathrm{ft}$. Ea. \$I.50.

We have a large variety in tubs. These can be transplanted at any time. We will be pleased to give list and prices on application In addition to Evergreens in tubs we have always a splendid lot of other stock useful for decorative purposes.

\section{Evergreens in Tubs.}

We have a large variety in tubs. These can be transplanted at any time. We will be pleased to give list and prices on application. In addition to Evergreens in tubs, we have always a splendid lot of other stock, useful for decorative purposes. 


\section{CLIPPED BOXWOOD.}

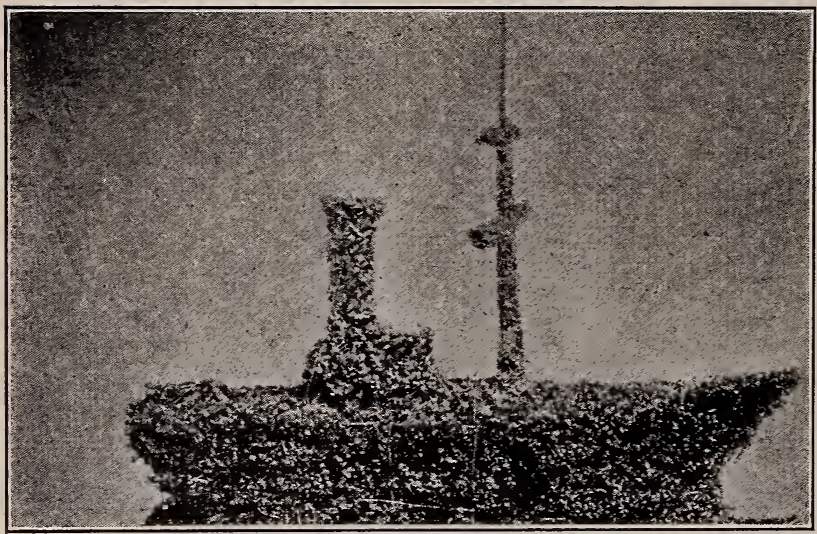

WE have been fortunate in securing from an old nursery in Europe a large variety of forms of

\section{BOXW00DS and YEWS}
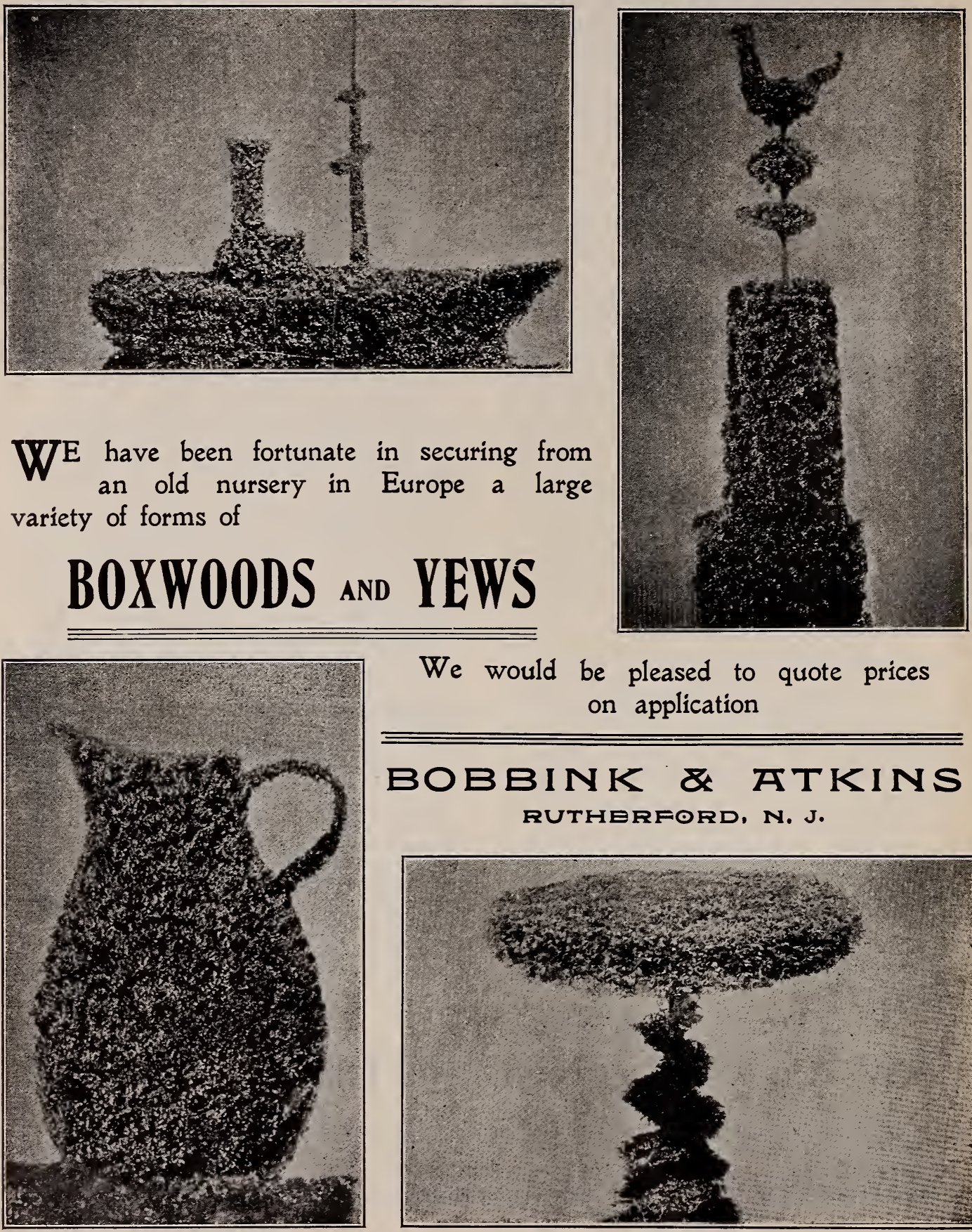

We would be pleased to quote prices on application

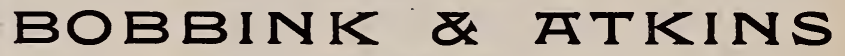
RUTHERFORD, N. J.

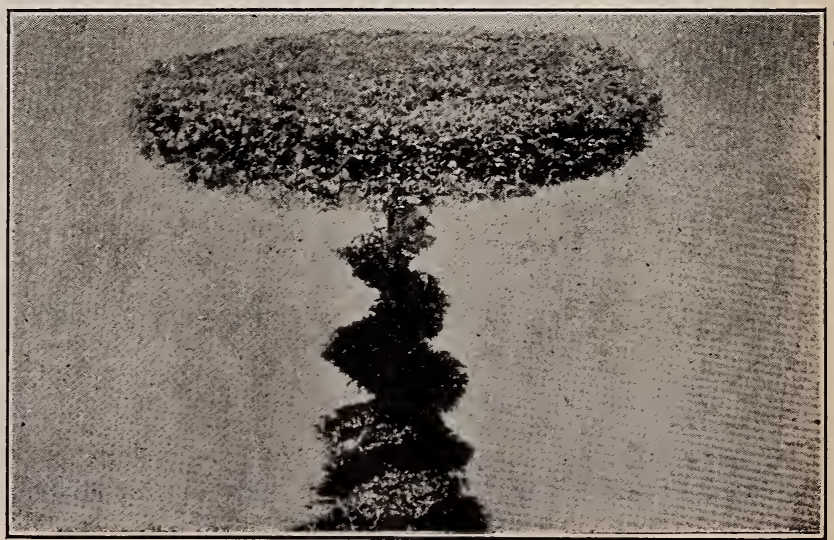




\section{Trained Fruit Trees for Fruit Houses and Gardens.}

The trained dwarf fruit trees, so universally used in Europe, are especially adapted for private places; they will be a source of pleasure, profit and interest, no matter if grown under glass, on garden walls or for border lines in the garden. We can supply them in different forms: Espaliers, Cordons, Fan-trained, Horizontal-trained, etc.

The main stem of these trees is 15 -I 8 inches, and covered with fruit branches ready to bear the first year. We have a very fine collection of Apples, Cherries, Pears, Plums, Peaches, Apricots, etc.

In varieties we have secured only the very best kinds; in Peaches especially, varieties with large fancy fruit such as seldom ripens on trees of ordinary form, but will ripen perfectly on these trees when trained on walls. Useful also for small gardens. Price, \$2.00, \$3.00 and \$5.00 each.

APPLES. Blenheim Pippin, King of the Pippins, Cellini Pippin, Sweet Morel, Kaiser Alexander, Nelson's Gloire, Baumann's Reinette, Princess Noble, Queen of Reinettes, Turner's Pippin, Hawthorne, Anana's Reinette, Colville Red, Yellow Transparent, Bismarck, Gravenstein, Golden Harvest, Lord Suffield, etc.

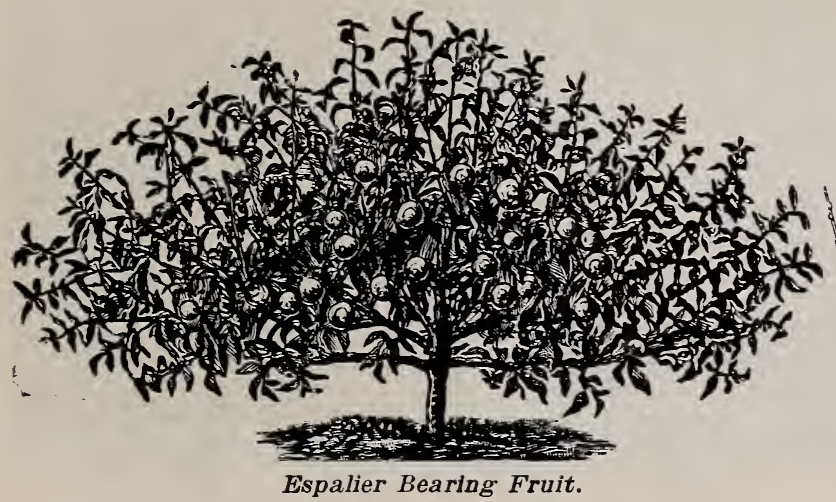

PEARS. Fertility, Nouveau Poiteau, Ananas de Courtrai, Bartlett, Clapp's Favorite, Lawson, Kieffer Seedling, Duc de Nemours, Idaho, Josephine de Malines, and others.

PEACHES. Early Crawford, Montague, Wilder's, Waterloo, Rouge de May, Royal George, Early Alexander, Richmond, Amsden.

Apricots and Cherries, in finest varieties.

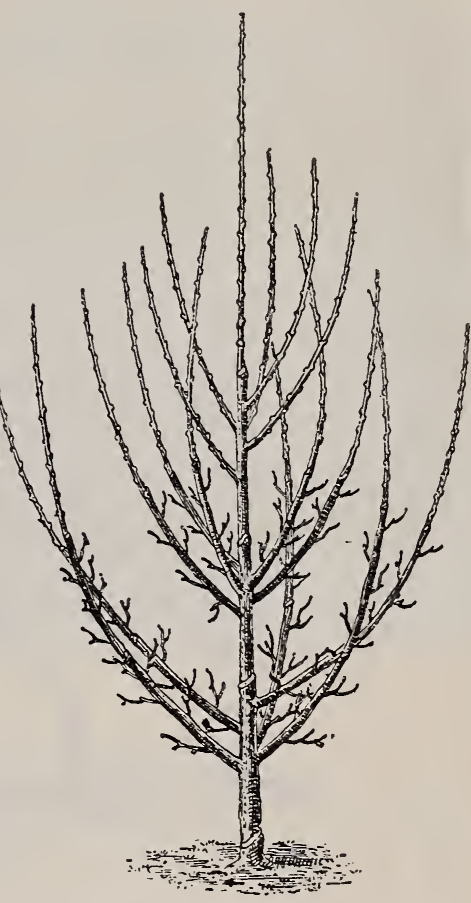

Pyramidal Trained Fruit Tree.

See Illustrations of Fruit Trees Cordon Trained, Page 28.

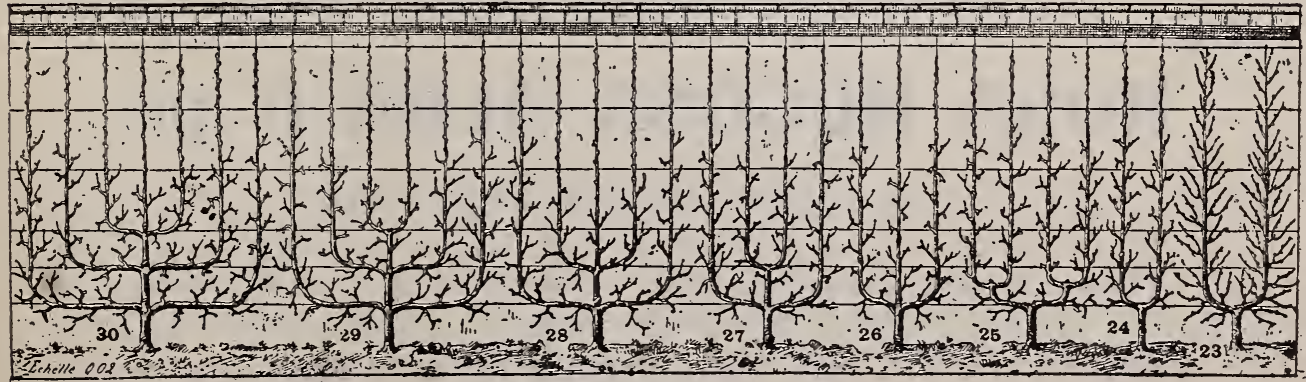

Fruit Trees-Trained "Espalier." 

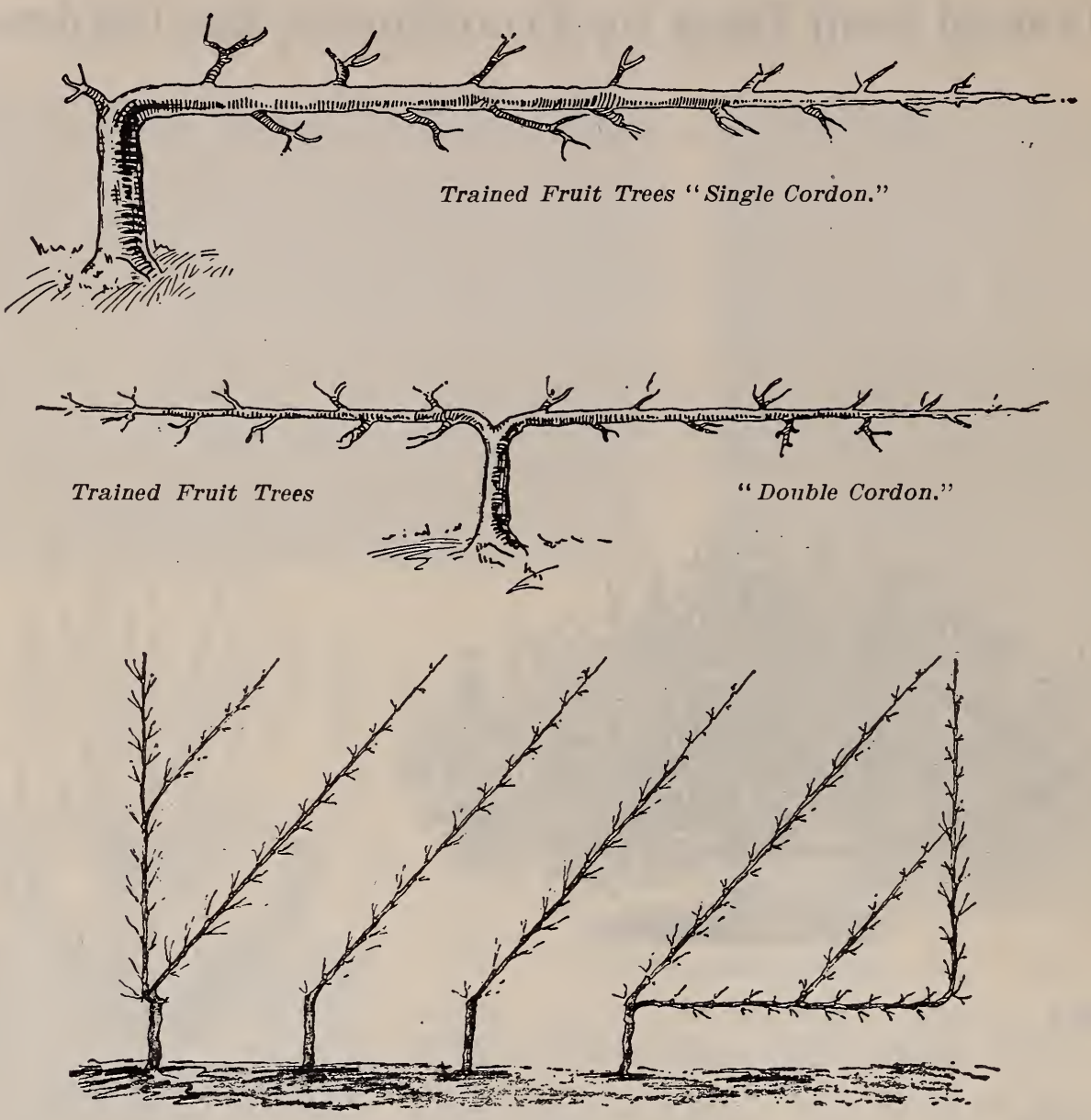

Fruit Trees "Cordon Trained."

One of our novelties for next Spring will be

\section{ROSA RUGOSA ALBA fl. pl.}

A NEW DÓUBLE FLOWERING RUGOSA ROSE.

This is a novelty of startling merit. Ask for price. Stock limited.

OUR NURSERIES ARE NOW THE MOST INTERESTING IN AMERICA. VISITORS ARE INVITED. 


\section{BAY TREES AND EVERGREENS.}

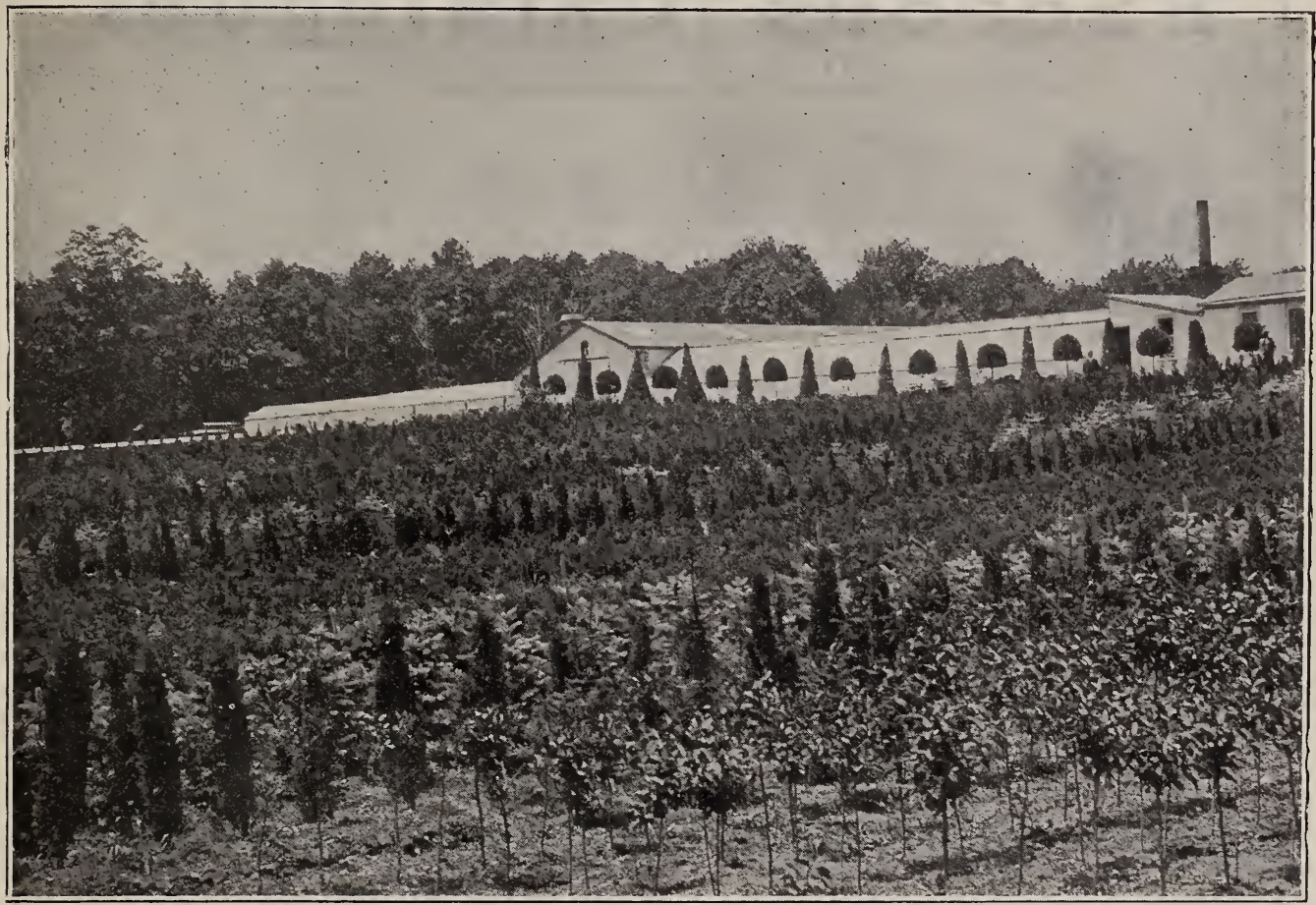

Collection of Evergreens and Bay Trees.

\section{STANDARDS.}

$2 \mathrm{ft}$. diameter of head. \$I5.00 per pair.

$2 \mathrm{ft}$. 6 in. diameter of head. \$20.0o per pair.

$3 \mathrm{ft}$. diameter of head. $\$ 25$. oo per pair.

$3 \mathrm{ft}$. $6 \mathrm{in}$. diameter of head. $\$ 35$. oo per pair.

$3 \mathrm{ft}$. ro in. diameter of head. \$40. oo per pair.

$4 \mathrm{ft}$. diameter of head. $\$ 45.00$ per pair.

Height of stem, 3 to $4 \mathrm{ft}$.

Extra specimens from $\$ 50.00$ to $\$ \mathbf{1}, 000.00$ per pair.

\section{PYRAMIDS}

About $5 \frac{1}{2} \mathrm{ft}$. high above tub. $\$ 25.00$ per pair; $6 \mathrm{ft}$, $\$ 30.00 ; 7 \mathrm{ft}$., \$35.00; $8 \mathrm{ft}$., \$40.00.

Extra large specimens, from $\$ 50.00$ to $\$ 250.00$ per pair.

AZALEA MADAME MOREUX. Splendid new Azalea. Great improvement on the well-known Vervaneana The flowers are more distinct in colors, larger and in form somewhat a camellia. Limited number of specimens on hand, 20 inches diameter, $\$ 6.00$ each.

AZALEA INDICA. In standard form. about 2 feet stem and 20 to 30 inches diameter of crown, in the very best sorts. Price $\$ 5.0^{\circ} \mathrm{O}, \$ 7.50$ and $\$$ I0.00 each.

ORANGE TREES. Young plants, 18 to $24 \mathrm{inch}$ head, on a stem of 18 to 20 inches high. Very attractive and fine for conservatory. $\$ 2.50$ each, $\$ 25$. Oo per dozen.

We have always many hundreds of Bay Trees from which you can select the trees you desire. Please ask for prices if you are unable to visit our Nurseries which , re interesting at all times. 


\section{Our General and Her- baceous Catalogues}

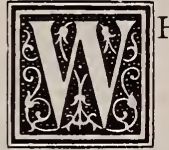

HILE we have made this Bulb Catalogue. for those who are especially interested in this class of stock, we have, in addition, issued our General Catalogues as in previous years, which will be found replete with Hardy Herbaceous Plants,

Evergreens and Conifers, of which we are large growers and importers; notable among them are Colorado Blue Spruce, Cedrus Atlantica glauca, Yews, Pinus, Junipers, and many others of equal grace and beauty.

In Ornamental Trees we carry a large stock of Golden, Black and Red Oaks, Purple and Weeping Beech, Golden Elm and Mountain Ash, Golden and Silver Poplars, and other fancy ornamental trees which would materially add to the beauty of the landscape when planted amongst a general variety of trees.

Flowering and Evergreen Shrubs have been given a place in this Catalogue; this they richly deserve, as no garden is complete and beautiful without them, including Rhododendrons, Azaleas, Amœna, Mollis and Ghent; also Lilacs, Spiræas, Mountain Laurel, and others too numerous to mention here.

Summer-flowering Bulbs have not been overlooked, Japan Lilies, Cactus, Dahlias, Cannas, Gladiolus, Gloxinias and Begonias being very conspicuous in our list.

Bay Trees and Boxwood in standard and pyramidal form, and clipped Boxwood Invitation

We should be pleased to have anybody interested in Horticulture visit our Establishment, which is situated at Carlton Hill, N. J. We have on hand at all times many interesting Plants, Shrubs, Trees and other stock. Our storehouses and greenhouses cover a superficial space of 100,000 square feet, and at this season the stock we have in them is worth traveling any distance to see. In addition to this, our large Nursery is always worth seeing.

Yours truly, BOBBINK \& ATKINS. in all shapes are in our storehouses.

Fruit Trees both in ordinary stock and trained trees, which have for many years been so popular in Europe, are also listed.

We will take pleasure in mailing these Catalogues free to prospective buyers.

\section{BOBBINK \& ATKINS.}




\section{B. \& A. Specialties}

Dutch, French, Japanese and Chinese Bulbs.

Azaleas and Rhododendrons for forcing.

BAY TREES and BOXWOOD.

EVERGREENS and BOXWOOD in tubs.

Palms, Boston and Assorted Ferns,

Rubbers and Fern Balls,

ROSES H. P. and EVERBLOOMING.

Tree, Crimson Ramblers and other Climbing Varieties.

Evergreens and Flowering Shrubs.

English Ivy and other Vines.

HARDY HERBACEOUS PLANTS

$$
\text { and ORNAMENTAL GRASSES. }
$$

WE HAVE THE FINEST LOT OF PALMS IN THE COUNTRY CALL AND SEE THEM.

Our sixty acres of Nursery are now the most interesting in America.

ASK FOR FALL BULB CATALOGUE.

BOBBINK \& ATKINS.

RUTHERFORD, N. J, 


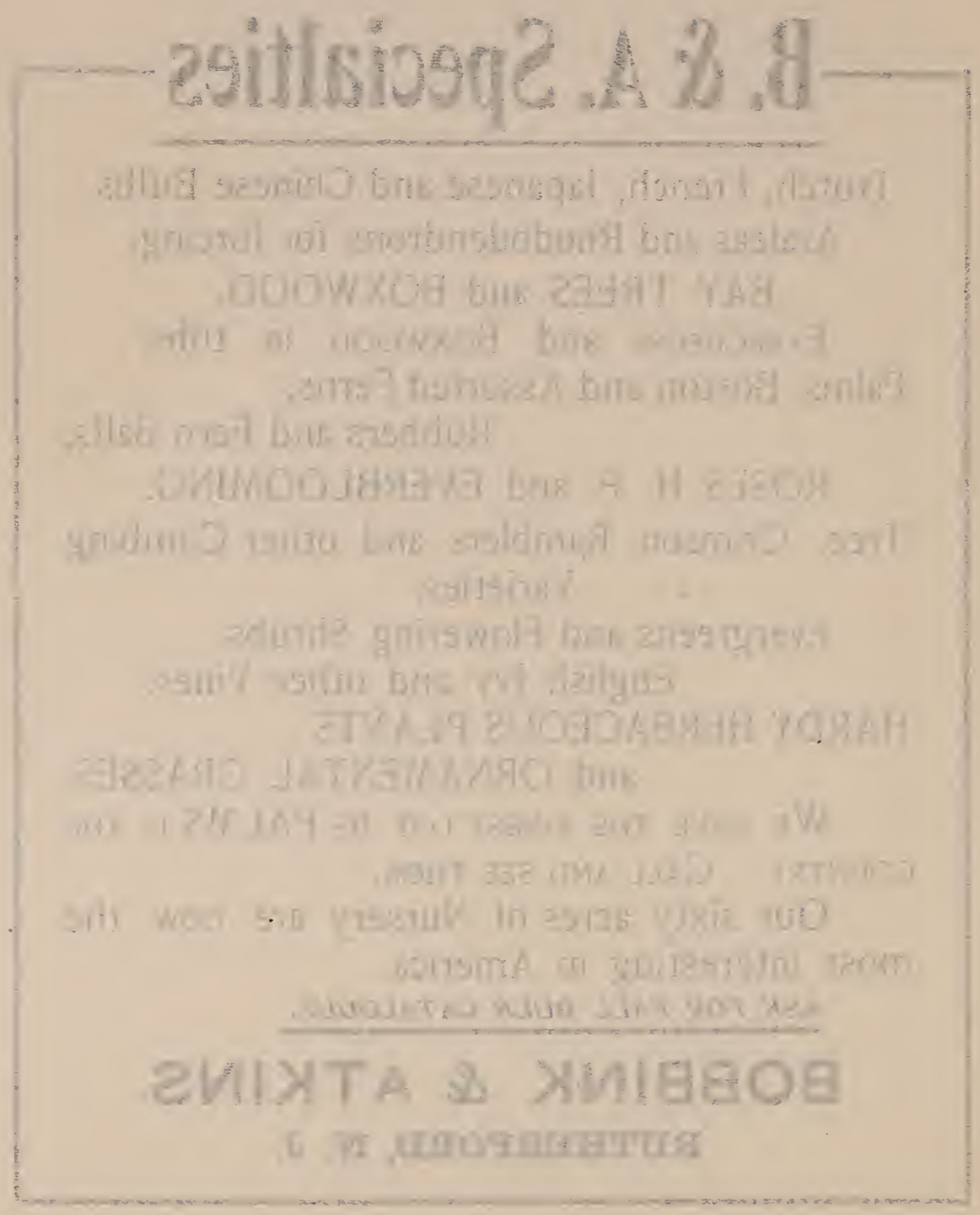




\section{"Rutherford Park" Lawn Urass Seed}

To obtain a beautiful lawn, one which is pleasing to the eye and a joy to the owner, you must be very particular in the selection of your grass seed. We recommend to you our "RUTHERFORD PARK" MIXTURE, which we have found very satisfactory in our extensive landscape gardening work, and which has given great satisfaction wherever used. We are the originators of this brand, wishing to have our own seed, on which we knew we could depend.

A great deal of your success with a beatiful lawn depends on the proper preparation of the soil. This should be done by draining, if necessary, and digging or plowing to the depth of 6 to 12 inches, according to the nature of the soil, applying at the same time a liberal quantity of well decomposed manure. Before sowing, the ground should be perfectly cleaned, made level, and evenly raked. The seed should be sown on a calm day, at the rate of 4 to 5 bushels to the acre. The ground should then be rolled, and, as soon as the grass has attained the height of 2 to 3 inches, rolled again. Frequent mowing and rolling are indispensable to maintain the turf in good order.

Our "RUTHERFORD PARK" MIXTURE will make a close, thick turf in a very few weeks. It roots deeply, enabling it to withstand severe droughts; consequently maintaining its beautiful rich green color the entire season. The "RUTHERFORD PARK" is no doubt the Cheapest Lawn Grass Seed offered; not particularly on account of the price, but more from a point of quality and quantity of seed to the bushel, which contains 2 I pounds of the finest kinds and varieties of grasses used for lawn purposes. We believe this mixture to be among the best now on the market, and would ask our customers to carefully consider this before placing their orders.

We will supply any quantity our customers may desire to meet the needs of the ground on which it is to be sown.

THE QUANTITY REQUIRED for making new lawns is 4 to 5 bushels to the acre; for renovating old lawns, I to 2 bushels. For a new plot, $15 \times 25 \mathrm{ft}$., or $375 \mathrm{sq}$. $\mathrm{ft}$., two quarts is required, and one quart for renovating old lawn of same dimensions.

Price, per qt., 25 cts.. peck, $\$ 1.50$; bush., $\$ 5.00$.

\section{Fertilizers for Lawn, Garden and Greenhouses.}

\section{PULVERIZED SHEEP MANURE.}

This is a pure natural manure-one of the best manures to mix with soil for potting plants-one part manure to six parts soil. For vegetable garden, placed directly in hills or drills, it promotes a rapid, steady growth until maturity. As a lawn top-dressing it is unequaled. IOo lbs., \$2.50; per ton, \$40.00.

\section{MEAT, BLOOD AND BONE}

ground up together. This we find the finest of all for all purposes. Gives quick and lasting results. Fine for lawns, gardens and greenhouse work. We can recommend this as one of the best. Put up in 250 to $300-1 \mathrm{~b}$. barrels at the rate of $\$ 40.00$ per ton.

\section{BONE FERTILIZERS.}

Contain 40 to 50 per cent. phosphate of lime and nitrogen, equal to about 4 per cent. ammonia. Decompose slowly in the soil and therefore form excellent permanent improvement, being less likely than almost any other kind of manure to waste in rainy seasons, particularly on sandy soils. There is no danger of burning the plants, whether applied as topdressing or directly to the roots. Excellent for top-dressing lawns and grass lands, for garden and field crops.

\section{QUANTITY REQUIRED.}

For trees and vines, 2 to 4 quarts each. For top-dressing, I000 to $1500 \mathrm{lbs}$. per acre. For field and garden crops, $3 / 4$ ton broadcasted and harrowed in. For rose beds, pot plants, etc., I part to about 50 of soil.

\section{RAW BONE MEAL.}

Ground finely, decomposes more rapidly in the soil than the coarser grades, and is therefore more quickly beneficial.

Price: Ioo-lb. bag, \$2.25; 200-1b. bag, \$4.00; per ton of 2000 lbs., $\$ 35.00$.

\section{RAW GROUND BONE.}

Not as fine as the meal, particularly adapted for general fertilizing; the finer particles are immediately beneficial, the coarse keeping up the supply of food for the plants for a long period.

Price: Per 100-1b. bag, $\$ 2.00$; per ton of 2000 lbs., $\$ 35.00$.

\section{GENUINE PERUVIAN GUANO.}

We have been fortunate in making arrangements with parties doing business in the islands of Lobos de Afuera, situate off the coast of Peru, to secure any quantity of this valuable and well-known fertilizer. We have any quantity to sell, and can ship at once upon receipt of order.

Original bags, containing 165 lbs., $\$ 7.00$; per ton, $\$ 45.00$. 


\section{Landscape Gardening.}

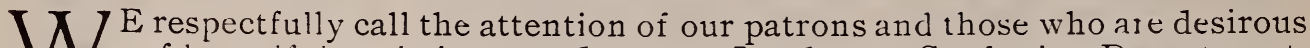
of beautifying their grounds, to our Landscape Gardening Department. We have proficient landscape arcinitects, gardeners, and artists in our employ who have a thorough knowledge of landscape work of every description. This is an important subject, and one that should not in any case be neglected as, when a residence is in course of construction, the grounds are entitled to the same consideration. Being often called upon to give advice as to the selection of proper trees and hardy plants for the planting of nurseries, pleasure and private grounds, parks, school grounds, streets, etc., also to furnish plants for such, we have secured for the convenience of our customers the services of experienced landscape architects, and are in a position to undertake work of any magnitude. Can furnish at short notice planting plans, topographical drawings and advanced ideas on all kinds of work pertaining to the construction of private establishments. Do not lay out your place without first consulting us and visiting our nurseries. Inspect the immense stock of ornamental evergreen shrubs, boxwood trees, herbaceous plants, and other interesting stock we have on hand and ascertain for yourself our magnificent facilities for making your place 2 perfect Garden of Eden.

\section{Shrubs, Trees, Fvergreens, Plants, Bullbs, Palms, Fepns, opehids and other \\ Not enumerated in this \\ list can be supplied at the lowest market cost} $\bigvee \begin{gathered}\mathrm{E} \text { will be pleased to have anyone desirous of purchasing this } \\ \text { stock submit their lists of wants for our lowest prices. }\end{gathered}$

Parties furnishing conșervatories, stocking greenhouses or laying out new grounds will make money by consulting with us. We will call upon you by request and submit estimates.

We are always in the market for large Palms and stock of all kinds, and will be pleased to hear from collectors and raisers of new varieties of Plants, Orchids, Seeds, Bulbs, etc., with a view of purchasing or exchanging same.

CORRESPONDENCE INVITED.

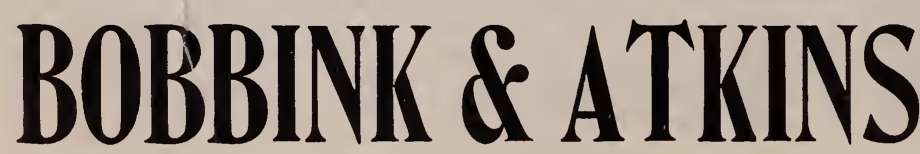

RUTHERFORD NEW JERSEY 